\title{
Economic Development Through Biomass System Integration: Summary Report
}

RECEIVED

JAN 101996

OSTI

Max M. DeLong

Northern States Power Company

Minneapolis, Minnesota

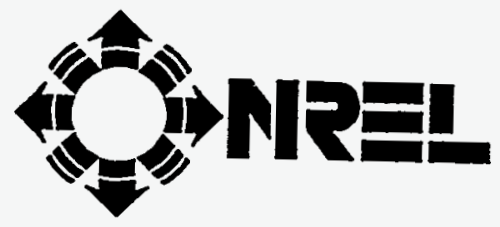

National Renewable Energy Laboratory 1617 Cole Boulevard

Golden, Colorado 80401-3393

A national laboratory of the U.S. Department of Energy Managed by the Midwest Research Institute for the U.S. Department of Energy

under Contract No. DE-AC36-83CH10093 
. 


\section{Economic Development Through Biomass System Integration: Summary Report}

Max M. DeLong Northern States Power Company Minneapolis, Minnesota

NREL Technical Monitor:

Kevin Craig

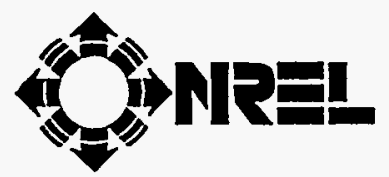

National Renewable Energy Laboratory 1617 Cole Boulevard Golden, Colorado 80401-3393

A national laboratory of the U.S. Department of Energy Managed by the Midwest Research Institute for the U.S. Department of Energy under Contract No. DE-AC36-83CH10093

Prepared under Subcontract No. AAE-5-14456-01

October 1995 


\section{NOTICE}

This report was prepared as an account of work sponsored by an agency of the United States government. Neither the United States govemment nor any agency thereof, nor any of their employees, makes any warranty, express or implied, or assumes any legal liability or responsibility for the accuracy, completeness, or usefulness of any information, apparatus, product, or process disclosed, or represents that its use would not infringe privately owned rights. Reference herein to any specific commercial product, process, or service by trade name, trademark, manufacturer, or otherwise does not necessarily constitute or imply its endorsement, recommendation, or favoring by the United States govemment or any agency thereof. The views and opinions of authors expressed herein do not necessarily state or reflect those of the United States government or any agency thereof.

Available to DOE and DOE contractors from:

Office of Scientific and Technical Information (OSTI)

P.O. Box 62

Oak Ridge, TN 37831

Prices available by calling (615) $576-8401$

Available to the public from:

National Technical Information Service (NTIS)

U.S. Department of Commerce

5285 Port Royal Road

Springfield, VA 22161

(703) $487-4650$ 


\title{
Economic Development Through Biomass Systems Integration
}

\author{
FOREWARD
}

The National Renewable Energy Laboratory, U.S. Department of Energy (DOE) in cooperation with the Electric Power Research Institute (EPRI) set forth requirements for the development of renewable biomass electricity production in a Letter of Interest (LOI, RCA-3-13326) to perform cost-shared feasibility studies. The LOI stated:

"The objective of this requirement is to promote the development of integrated biomass production and conversion technologies. It is the goal of this requirement to enable the subcontrator [NSP] and NREL [National Renewable Energy Laboratory] and EPRI [Electric Power Research Institute] to evaluate the potential for early implementation of cost-shared field demonstrations or pre-commercial developments of integrated systems in anticipation of future joint ventures to commercialize these systems".

NREL, United States Department of Energy

Northern States Power Company (NSP), in response to this LOI contracted with the University of Minnesota, Westinghouse Electric Corporation, the Institute of Gas Technology (IGT), and Tampella Power Corporation to determine the technical and economic feasibility of a proposed Sustainable Biomass Energy Production system. The following summary report and supporting volumes respond to the tasks set forth in NSP's proposal to DOE and EPRI. 


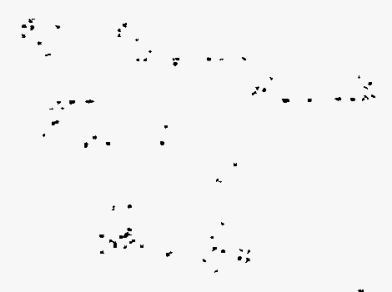




\title{
Economic Development Through \\ Biomass Systems Integration
}

\section{Sustainable Biomass Energy Production}

\begin{abstract}
Alfalfa is a well-known and widely-planted crop that offers environmental and soil conservation advantages when grown as a 4-year segment in a 7-year rotation with corn and soybeans. Alfalfa fixes nitrogen from the air, thereby enhancing soil nitrogen and decreasing the need for manufactured nitrogen fertilizer. With alfalfa yields of 4 dry tons per acre per year and the alfalfa leaf fraction sold as a high-value animal feed, the remaining alfalfa stem fraction can be economically viable fuel feedstock for a gasifier combined cycle power plant. This report is a feasibility study for an integrated biomass power system, where an energy crop (alfalfa) is the feedstock for a.processing plant and a power power plant (integrated gasification combined cycle) in a way that benefits the facility owners. The sale of an animal feed co-product and electricity both help cover the production cost of alfalfa and the feedstock processing cost, thereby requiring neither the electricity or leaf meal to carry the total cost. The power plant provides an important continous demand for the feedstock and results in continous supply of leaf product to provide a reliable supply needed for the leaf meal product.
\end{abstract}





\title{
Economic Development Through \\ Biomass Systems Integration
}

\section{Sustainable Biomass Energy Production}

\author{
EXECUTIVE SUMMARY
}

Alfalfa is a well-established nitrogen-fixing perennial crop that conserves soil. This report evaluates alfalfa-leaf meal as an animal-feed co-product along with an alfalfa-stem gasification combined cycle as a biomass power generation option.

\section{Background}

In response to a solicitation by USDOE managed by the the National Renewable Energy Laboratory (NREL), Northern States Power Company (NSP) joined with the University of Minnesota,The Institute of Gas Technology, Tampella Power Corp.and Westinghouse Electric Corp. to propose and then perform a feasibility study of alfalfa crop production coupled to a gasifier/gas cleanup/gas turbine/steam turbine power generation system. In accord with the solicitation by NREL, the study investigated economic development through biomass systems integration. emphasizing: 1) sustainable biomass energy crop production, 2) efficient feedstock use with gasifier/gas-turbine power generation, and 3) farmer owned value adding co-product production of alfalfa-leaf meal.

\section{Ohjective}

To answ the feasibility of a specific crop/power combination that could offer sustainable, envuronmentally progressive, economically viable power generation from a biomass energy crop sỵstem. 


\section{Approach}

The study team analyzed alfalfa production and marketing, including higher-value markets obtainable from an upgraded product. Integrated processing included separation of the highnitrogen bearing leaves from the low-nitrogen bearing stems, use of the stems as power plant fuel, upgrading the leaves to an even higher-value feed using waste heat from the power plant, and a joint venture business arrangement between a farmers' cooperative and the power plant owner/operator. The study team analyzed design options, performance and economics of mechanical and power systems for feedstock handling, gasification, gas cleanup, and combinedcycle power generation. The team prepared a report covering all aspects of the integrated agricultural and power generation systems, including an assessment of the resource base in the counties surrounding the power plant site near the City of Granite Falls in southwestern Minnesota.

\section{Results}

Based on currently achieved alfalfa yields of approximately 4 dry tons per acre per year, a 4-year alfalfa segment can be integrated with corn and soybeans in a rotation system that maintains income to the farmer comparable to a traditional continous corn-soy bean cropping rotation system. The system provides the benefits of less fertilizer use, better soil conservation, the potential for improved wildlife habitat, and the potential for adequate farm income with decreased price. supports. The gasification system has been identified. Preliminary tests, reported in this study indicate that gasifier fly ash is not molten or sticky and can be cleaned out of the gas stream without clogging the filters that remove particulate matter. Costs for a demonstration power system, a DOE/industry-co-op cost shared joint venture, are projected to be low enough to be competitive with other biomass baseload alternatives for new generating capacity. Specifically, total plant cost for $75 \mathrm{MWE}$ (net) unit size is $\$ 1643 / \mathrm{kW}$ plus $\$ 167 / \mathrm{kW}$ for the alfalfa processing plant. Adding $\$ 120 / \mathrm{kW}$ for interest during construction gives a total plant investment of $\$ 1929 / \mathrm{kW}$. Using an average annual return of $11.5 \%$ on the initial equity amount, and a capacity factor of $85 \%$, the 15 -year levelized cost of electricity is $6.52 \phi / \mathrm{kWh}$ (constant 1994 dollars), assuming a 1/3 federal capital cost share and a 5-year tax life. 


\title{
TABLE OF CONTENTS
}

\author{
SUMMARY \\ FOR \\ GENERATION OF ELECTRICITY AND CO-PRODUCT PROCESSING \\ FROM \\ ALFALFA PRODUCED IN SOUTHWESTERN MINNESOTA
}

Page

INTRODUCTION ..................................................................................................................................

FEASIBILITY STUDY CONCLUSIONS........................................................................................ 3

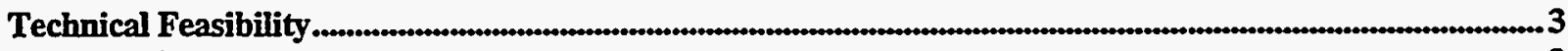

Economic Feasibility.....1.

TASK 1. PROJECT CONCEPT \& DESCRIPTION ...................................................................... 4

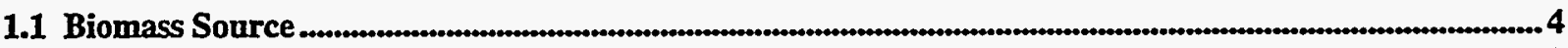

1.2 Conversion Technology Selection.

1.3 Business Viability Projection........ 10

TASK 2. BUSINESS PLAN ............................................................................................... 12

2.1 Introduction And Background ..5.

2.2 Joint Venture Description.

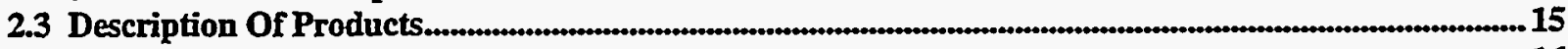

2.4 Product Cost Analysis

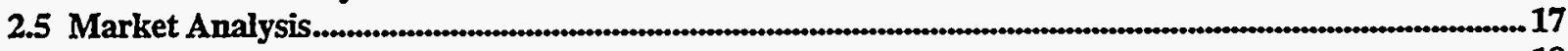

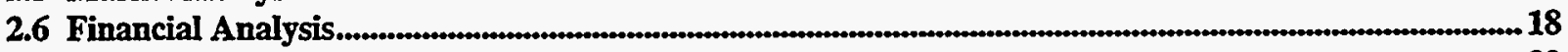

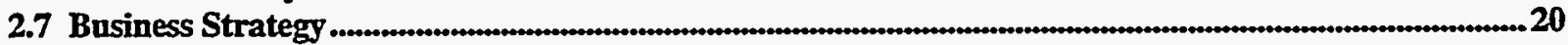

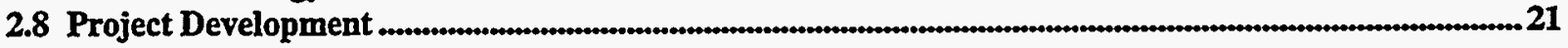

TASK 3. THE DEDICATED FEEDSTOCK SUPPLY SYSTEM (DFSS) ................................... 23

3.1 An Alfalfa Based DFSS ...1.

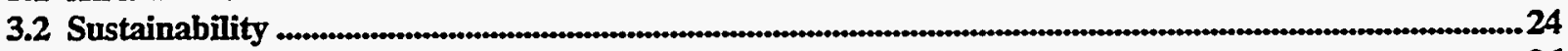

3.3 Alfalfa Production .

3.4 Production Economics

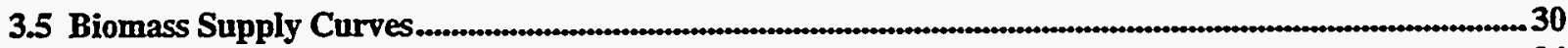

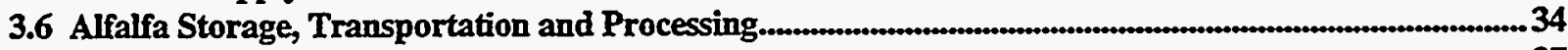

3.7 Alternative Feedstock Resources...5.

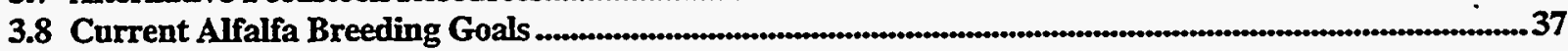

TASK 4. THE CONVERSION TECHNOLOGY ......................................................................... 39

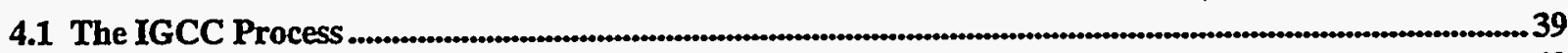

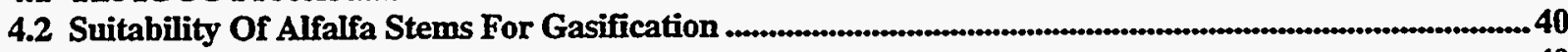

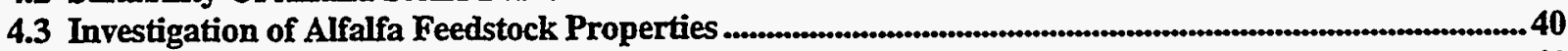

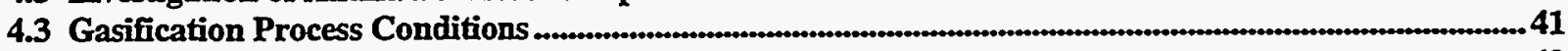

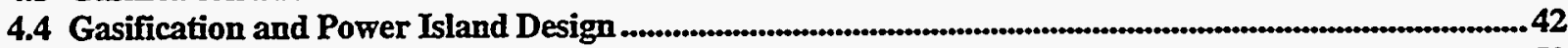

4.5 Plant Operation and Maintenance...n.

4.6 IGCC Plant Performance. 
TASK 5. ENVIRONMENTAL MONITORING ........................................................................55

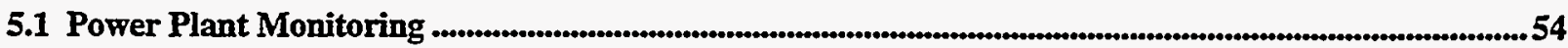

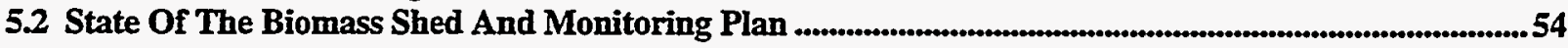

TASK 6. MARKET ISSUES............................................................................................................55

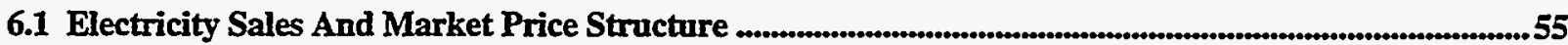

6.2 Co-Product Sales And Market Price Structure ....n.

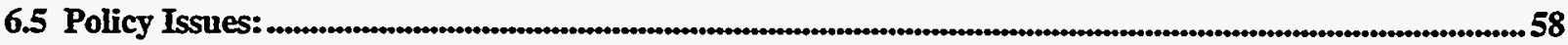

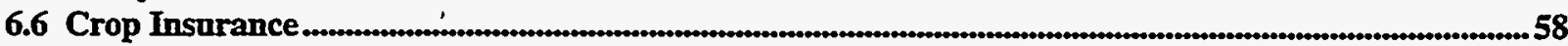

TASK 7. SOCIO-ECONOMIC \& ENVIRONMENTAL IMPACT ...............................................59

7.1 Economic Impact

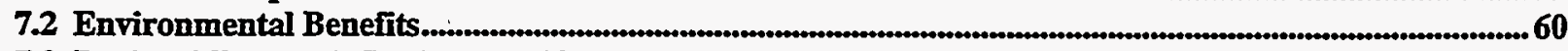

7.3 Regional Economic Projections (Costs And Benefits)

VOLUME 1: DEDICATED FEEDSTOCK SUPPLY SYSTEM

VOLUME 2: CONVERSION TECHNOLOGY

VOLUME 3: BUSINESS PLAN

VOLUME 4: SITE CONSIDERATIONS

LIST OF TABLES

Page

TABLE 2-1 COMPARISON OF COE FOR DIFFERENT BIOMASS GENERATION OPTIONS...........................17

TABLE 2-2 VALUE OF ALFALFA LEAF MEAL IN DAIRY RATIONS .........................................................

TABLE 2-3 SUMMARY OF COST SHARE AND TAX CREDIT INFLUENCE ...................................................19

TABLE 3-1 CROP ACREAGES AND ALFALFA YIELD BY COUNTY FOR THE BIOMASS SHED ................28

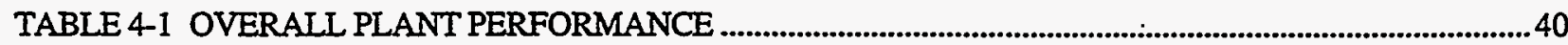

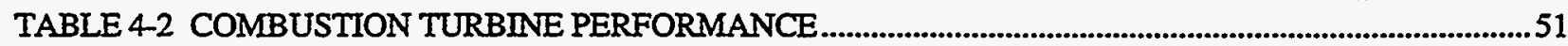

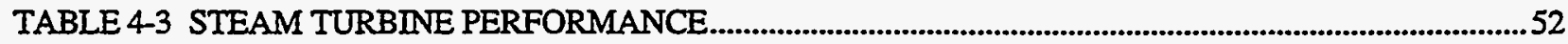

TABLE 4-4 TOTAL IGCC EMISSIONS AT FULL LOAD

\section{LIST OF FIGURES}

FIGURE 1-1 MAP OF SOUTHERN MINNESOTA SHOWING THE BIOMASS PRODUCTION AREA...............5

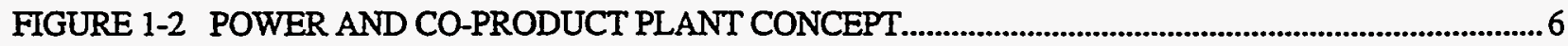

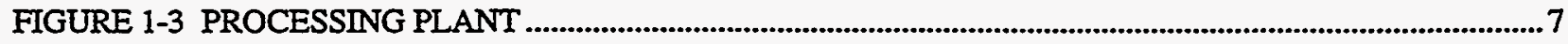

FIGURE 1-4 THE TAMPELIA IGCC PROCESS FOR BIOMASS - 75 MW, NET ..............................................9

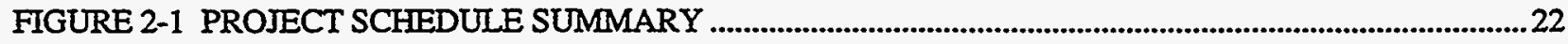

FIGURE 3-1 PRODUCTION REGIONS WITHIN THE BIOMASS SHED ....................................................32

FIGURE 3-2 BASELINE REGIONAL BIOMASS SUPPLY CURVE AND ADOPTION RATE FUNCTION.......33

FIGURE 4-1 WESTINGHOUSE 251B12 COMBUSTION TURBINE ............................................................43

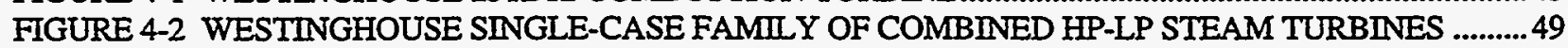




\section{INTRODUCTION}

The US Department of Energy's National Biomass Power Program takes the following position:-Biomass power can make a tremendous contribution to domestic and international energy needs while addresssing broader enviromental requirements. More than any other energy technology, biomass power is capable of contributing to the nation's energy needs while decoupling energy production from environmental degradation. Expanded investment in biomass energy technology can create new income and jobs, strengthen U. S. industrial competitiveness and provide economic development for areas in rural America. Todays biomass industry is based on conventional combustion technologies, but these require technical and cost improvements. (USDOE, National Biomass Power Program Five Year Plan).

In order to acomplish these goals, USDOE, with direction by the National Renewable Energy Laboratory, has developed technology and assisted in transferring technological advancements into the market place with risk reduction through joint ventures with industry. They have conducted market conditioning efforts through working with potential users to mitigate market and regulatory barriers to using biomass technologies. Various joint ventures such as this feasibility study and possibly future cost shared, collaborative commercialization demonstration projects are also a part of the plan to accelerate the acceptance of new technologies.

This report analyses the technical and economic feasibility of producing $75 \mathrm{MW}$ of baseload electricity from a dedicated biomass energy crop (alfalfa) by an integrated gasification combined cycle (IGCC) electric power generation conversion process. A site in southwestern Minnesota at an existing NSP power plant, near Granite Falls, Minnesota, was chosen for the feasibility study. The area within a 50 mile radius of this site has been defined as the dedicated feedstock production region or biomass shed. Dedicated biomass crops, namely those planted specifically for energy production, are needed to assure long-term reliable feedstock supplies for baseload power generation.

Biomass is a general term that describes all biological material. Typical biomass energy sources studied in the past include: hybrid poplar, switchgrass, waste-wood, and crop residues. The production/collection of large quantities of biomass close to a power plant has often been the critical factor determining the economic viability of biomass energy production systems. For this 
reason, other biomass energy systems have focused on a) concentrating tesidues from other agricultural or forest operations, or b) maximizing biomass crop yields per acre to achieve economic feasibility.

Although yield is an important factor in alfalfa production, it is not the critical factor in this system. What is critical in this system is the integration of agricultural production and electric power production so two competitive and viable products enable a joint venture to be economically feasible. Integration in this system provides progress toward more sustainable land management practices, while providing enhanced economic outlets for the available photosynthate constituents of alfalfa. The integration of agricultural production and energy production benefits both systems. Efficiency is the goal. 


\section{FEASIBILITY STUDY CONCLUSIONS}

\section{Technical Feasibility}

Reliable and economic fuel supply and generating efficiency have been the significant problem areas in the past for biomass energy options. USDOE believes these aspects of biomass power, if not resolved, will inhibit the competitiveness of this approach compared to traditional means of power generation. This study has addressed those issues.

The feedstock for fuel supply for this concept is alfalfa. It is a crop already grown in the biomass shed. Farmers indicate they would like to grow more alfalfa to accomplish improve plant diversity in their cropping systems. There is sufficient land available in the biomass shed ( 50 mile radius from the plant) available to grow alfalfa, and the required 180,000 acres would require only about : $6 \%$ of the tillable land in the area. The study has provided data to demonstrate the technical 'feasibility of alfalfa as a feedstock for biomass fuel that could be provided in quantities sufficient for a 75 Mwe plant over the life of a project.

The fuel preparation technology and integrated gasification combined cycle (IGCC) conversion technologies selected for the project are ready for commercialization demonstration. Parts of these systems are already commercially available, or have been demonstrated at pilot facilities and are technically feasible for the proposed use. Further, the use of these technologies have a projected efficsency to allow reasonable fuel usage.

\section{Economic Feasibility}

The pronductuon of electricity and an animal feed co-product can be done in a combination that allows these prixuits to be priced at levels that appear to be competitive in the market and provide return on investment surtable for these kinds of businesses.

The prowuction of alfalfa can be accomplished at a cost of feedstock that would likely be acceptable to the joint venture and a payment to the farmers that would be competitive with alternatives they have from rausing other crops. 


\section{TASK 1. PROJECT CONCEPT \& DESCRIPTION}

\subsection{Biomass Source}

\subsubsection{Existing Capability}

Alfalfa, an herbaceous perennial legume, is proposed as the dedicated biomass energy crop. Minnesota farmers currently produce over 6.9 million tons of alfalfa hay per year, the fourth largest production level of alfalfa in the country. However, alfalfa acreage covers less than $6 \%$ of Minnesota's total cropland (Minnesota Agricultural Statistics 1992). The proposed production area for alfalfa (biomass shed) is defined for this study as an area within a 50 mile radius of Granite Falls, Minnesota (Fig 1-1). The farmland within the counties touched by the 50 mile radius currently produce 0.34 million acres alfalfa. In these same counties, 5.4 million acres of corn and soybeans are produced. The size of the average farm in the shed is 580 acres.

Based on focus group interviews potential biomass producers would be experienced farmers already operating farms in the biomass shed. These farmers would be motivated to start producing or increase their production of alfalfa to increase profitability, reduce risk through diversification, and enhance environmental quality on their farms.

\subsubsection{Sustainable Biomass Production}

The proposed cropping plan involves planting alfalfa in a seven year cycle, with 4 years of alfalfa followed by 2 years of corn and one year of soybeans (AAAACCS). Alfalfa is planted in the spring of the first year,and one cutting is taken near the end of August that year. Alfalfa production continues for years two, three and four with three cuttings per year being harvested. Following that ,com is grown two years in sucession, and in the seventh year soybeans are be grown. The addition of alfalfa provides plant diversity in cropping rotations to enhance preservation and the productivity of the land.

Including alfalfa in the rotation provides: increased yield from other crops in the rotation, reduced external inputs of nitrogen and lowers overall production costs (fossil fuel inputs). Environmental benefits include reduced soil erosion (sheet and rill water erosion by $60 \%$, and wind erosion by $45 \%$ )., improved soil tilth, increased soil organic matter levels, reduced potential for nitrate leaching, and a reduction in diffuse source pollutants.. 
Figure 1-1 Map of Southern Minnesota Showing The Biomass Production Area

(The Region Within a 50-Mile Radius of Granite Falls in Southwestern Minnesota)

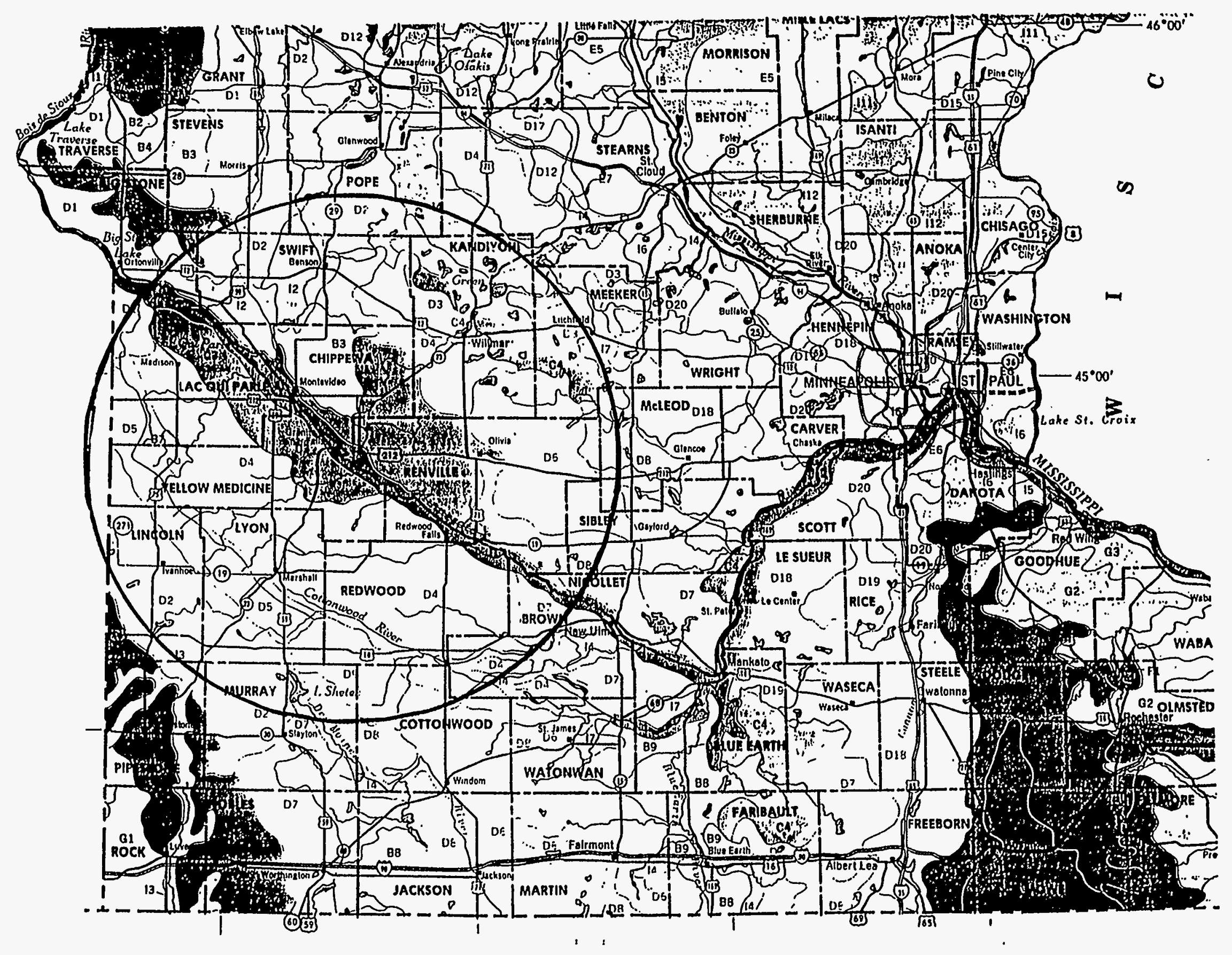


Establishing additional acreage of alfalfa in the area surrounding Granite Falls will have a significant impact on the abundance and diversity of wildlife in the area. This concept could eventually be operated with an alfalfa harvest schedule of two-cuttings per year (late June and late August), and this would have very significant positive impacts on both wildlife abundance and diversity. The proposed two cut system could be in operation within about 6 years.

\subsubsection{Two Revenue Streams}

Growing alfalfa, or any other intensively managed crop on productive agricultural land, means there is a substantial cost of production which must be supported by the sale of the products produced from the feedstock. In this concept (see Figure 1-2) two revenue streams occur; one from the sale of electricity and the other from the sale of a co-product of a mid-level, by-pass protein as an ingredient for animal feed. Each product shares the cost of production, and thus neither has to bear the entire cost.

\subsubsection{Dual Purpose Feedstock Separation Process}

The alfalfa processing plant uses, in part, technology that has been developed over the last 40 years for the alfalfa dehydration industry. In the processing plant, the alfalfa is dried, in a rotary kiln dryer before separating the leaves from the stems (see Figure 1-3). The separation process also uses a fractionating hammermill designed specifically for the separation of alfalfa leaves from stems.

Figure 1-2 Power And Co-Product Plant Concept

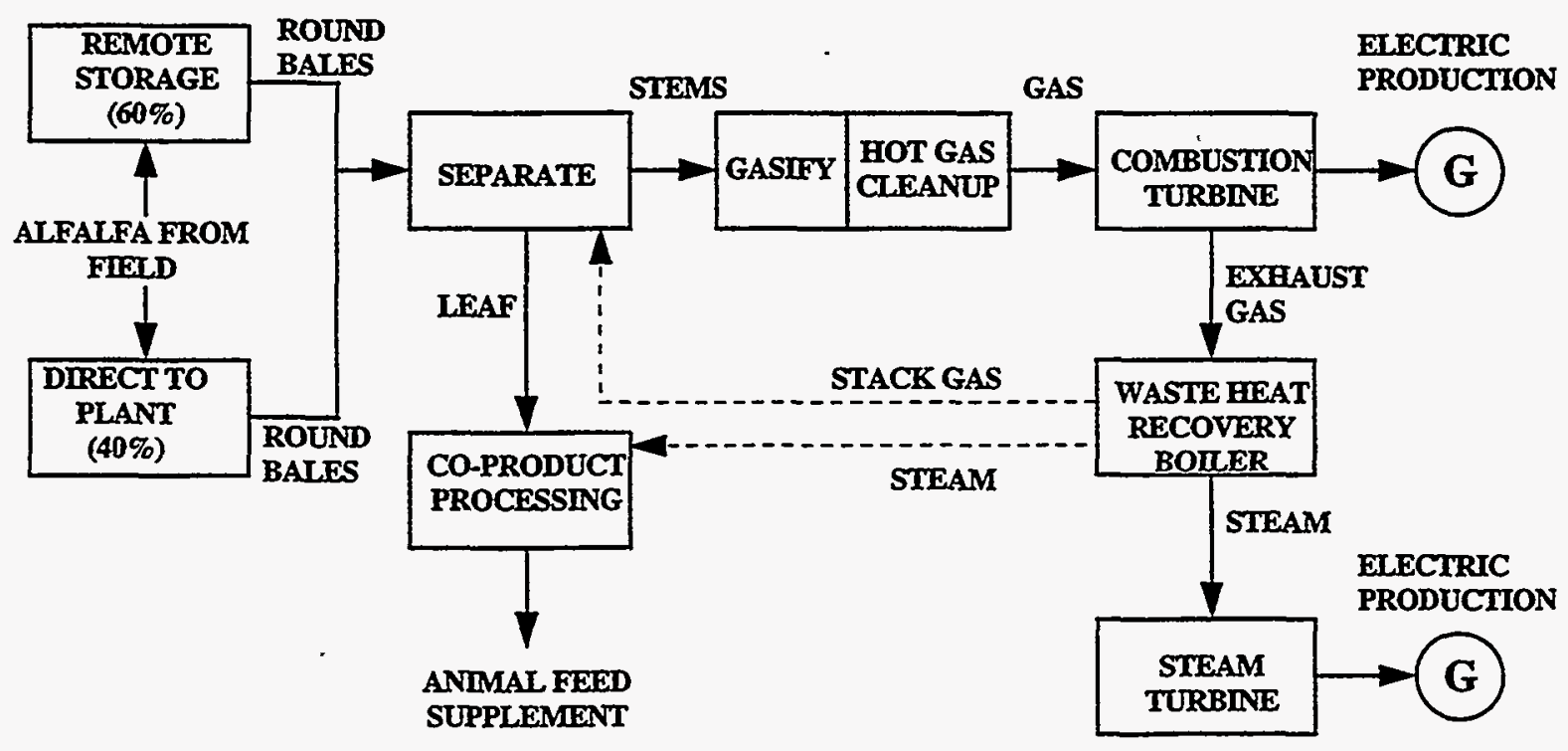




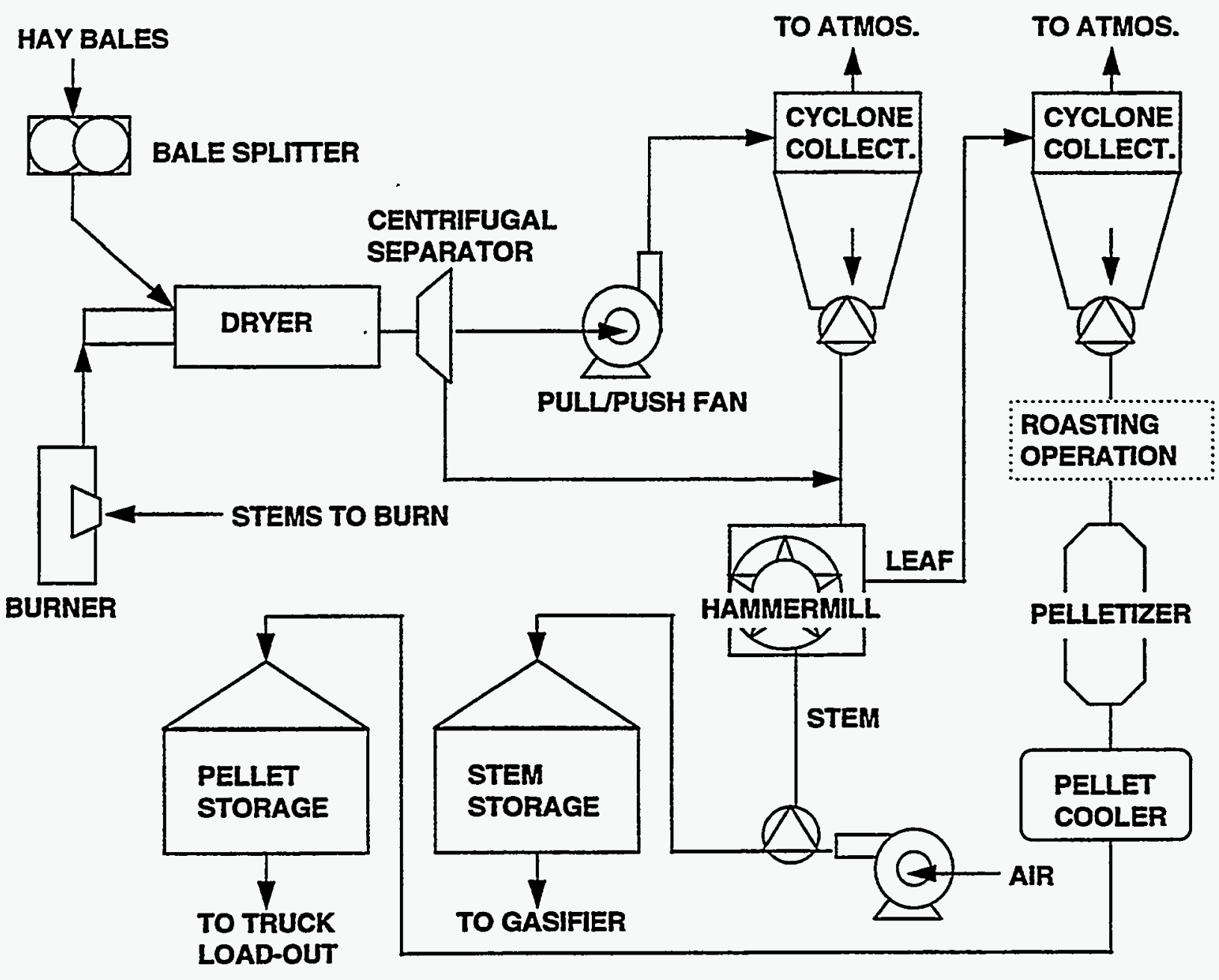

Removal of the fiber from the leaf material raises the value of the leaf meal. Separation of the leaf material from the fiber fraction, removes significant fuel bound nitrogen from the fuel (stem) fraction which lowers $\mathrm{NO}_{\mathrm{X}}$ production in the turbine.

\subsubsection{Energy Balance}

The ratio of energy input to energy output (energy balance) for this system has been calculated. This sustainable biomass energy production system has a positive energy balance. Energy balance is a measure of system efficiency. Total system efficiency for the production of leaf meal and electricity from alfalfa is 1:3 (for each unit of energy input the system produces 3 units of energy output). Energy balance calculations and comparisons are presented in Volume 1(10). 


\subsection{Conversion Technology Selection}

\subsubsection{High Carbon Conversion Biomass Gasification}

Electricity is produced from the alfalfa stems in an IGCC power plant. In the gasifier, the alfalfa stems are rapidly heated to gasification temperatures approaching $1650^{\circ} \mathrm{F}$ and a lo-Btu gas is produced. In a combined-cycle power plant electricity is produced by two separately powered turbine/generators. In the first cycle the turbine is powered by the combustion of biomass gas. The fuel for the combustion turbine is provided by the gasification of the alfalfa stems. The heat in the exhaust gas from the combustion turbine is reclaimed as steam in a heat recovery-steam generator (HRSG). This steam is used to power the turbine in the second cycle (see Figure. 1-4). The gasification process, provides high carbon conversion and low tar production which results in very efficient use of the alfalfa stem feedstock.

The combustion turbine is one of Westinghouse's standard industrial designs, which has been modified to accommodate low-Btu biogas fuel. The turbine is equipped with Westinghouse's stateof-the-art gas combustion system, which represents the Best Achievable Control Technology (BACT) for the mitigation of $\mathrm{NO}_{\mathrm{x}}$ in combustion turbines. About 50.1 MW of electrical power is produced in the gas turbine generator.

The usable heat remaining in hot combustion gases leaving the gas turbine is recovered in the heat recovery steam generator (HRSG) in the form of superheated, high-pressure steam. The steam is used to produce an additional $29.3 \mathrm{MW}$ in the steam turbine generator. The stack gases leaving the HRSG meet or exceed all air quality requirements.

From the total 79.4 MW produced in the IGCC plant, $4.3 \mathrm{MW}$ is used internally as auxiliary equipment power, thus producing net power of $75.1 \mathrm{MW}$. The overall performance for the Alfagas IGCC plant is summarized in Table 4-1. The plant costs and economic analysis are presented in the Economics and Business Plan, Volume 3. 


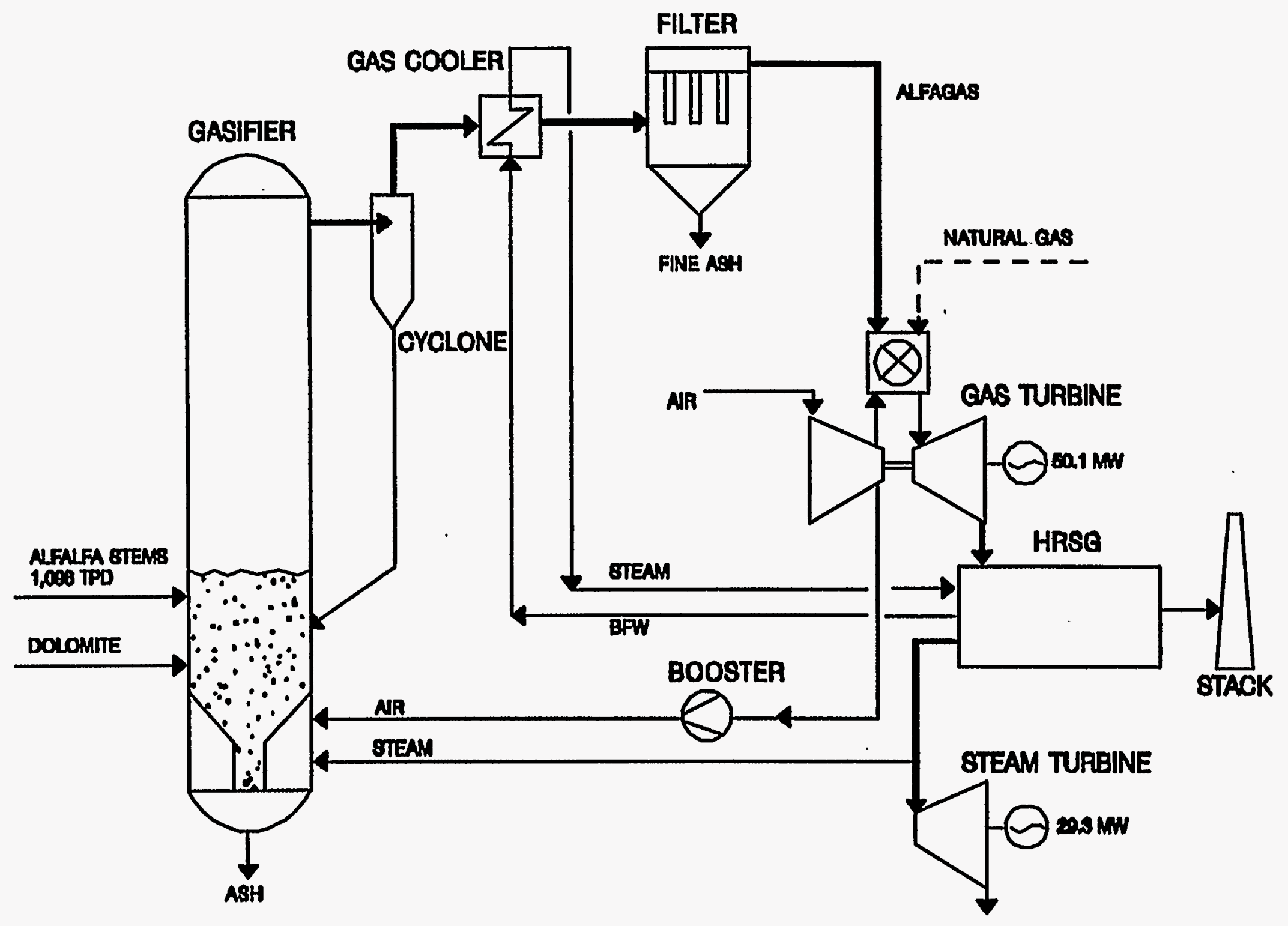

Figure 1-4 The Tampella IGCC Process For Biomass - 75 Mw, Net 


\subsubsection{Particulate Removal With Hot Gas Clean Up}

The gases leaving the gasifier are cooled to $1020^{\circ} \mathrm{F}$ to allow volatile alkali species to plate out on the ash and bed dust that is carried over. The gas is then cleaned with a high temperature ceramic filter system allowing the fuel gas entering the gas turbine to meet the manufacturer's requirements. The particulate-laden fuel gas from the gasifier is cleaned in the hot gas cleanup unit (HGCU). High-temperature particulate-laden gas enters the filter vessel and the ash collects on the outer surface of the ceramic filter elements. The clean gas passes through the filters and into the clean side of the filter elements. This produces a suitably low particulate bearing gas, which proceeds to the combustion turbine. The particulate cake formed on the ceramic filters has suitable consistency to allow cleaning by back pulsing with nitrogen gas without re-entrainmentof the particulate.

\subsubsection{Low-Btu Gas Compatible Power Island}

The product gas from air-blown alfalfa gasification differs from traditional combustion turbine fuels in three ways: first, it has a lower heating value (approximately $15 \%$ of the value of natural gas); second, the gasifier product gas will enter the combustion turbine at $1020^{\circ} \mathrm{F}$; and third, it contains significant quantities of fuel bound nitrogen (FBN). Certain design considerations must be made to the combustion turbine to address these fuel characteristics. The high-temperature, low-Btu fuel combustors must meet emission levels while operating on biogas, natural gas (backup fuel), or a combination of both.

The leading candidate is the combustion system used on two Westinghouse 501D5 combustion in service for over 6 years. An alternate combustion system being considered is the multiannular swirl burner.

\subsubsection{Integrated Facility}

The integration of the IGCC plant with the alfalfa processing plant accomodates the heat requirement for the drying of the alfalfa bales that are received by the alfalfa processing plant, and the heat requirement for the alfalfa leaf processing.

\subsection{Business Viability Projection}

\subsubsection{Joint Venture With Expertise And Incentives}

A joint-venture between a farmer owned cooperative and an electric utility entity proposed as an efficient business structure for successful cost-shared demonstration of biomass energy production. As the result of grower meetings in the Granite Falls area, a group of interested farmers have formed the "Minnesota Valley Alfalfa Producers Cooperative". This agricultural 
cooperative was established in late 1994, specifically to evaluate business opportunities such as might arise from adaptation of this concept.

\subsubsection{Competitive Priced Products}

The cost of electricity (COE) has been calculated at 6.52 cents per $\mathrm{kWhr}$ for a base case situation with one-third cost share. Compared to other biomass options evaluated by EPRI, the COE for this concept is competitve.

\subsubsection{Suitable Return On Investment}

The revenue for the base case financial analysis of this concept is derived from the sale of electricity (43\%)and co-product (57\%). The target for the average annual return on the initial equity has been set at $11.5 \%$. This level of return on investment is justifiable where a portion of revenue is from a stable power sales agreement and a portion is from a variable market like leaf meal.

\subsubsection{Certification And Permitting Of The Facility}

This concept is consistent with the focus of the regulatory agency guidance that suggests the use of biomass energy sources to accomplish energy independence and a reduction in emissions that might be considered climate change agents. Permitting of the processing and power plant facility would be compatible with existing regulations, and would be very similar to other power plant facilities. The sustainability of the agricultural production aspects of this concept provides a way to achieve the regional targets of improving the biomass shed environment. The concept could in fact leverage many of the other activities under way to improve the environment so permitting of the biomass production (if any might be required) should not be contrary to existing philosophy. It also has a rural economic development facet that is of great interest to the comunities and the local and regional industrial and commercial development organizations. so certification of the facility should be consistent with prevailing socio-economic goals.

\subsubsection{Future Business Growth Potential}

The protein in alfalfa can be extracted by means other that the mechanical separation considered for this feasibility study. If the protein is extracted in a liquid form, the material may have a much higher value as a constutuent in cosmetics or human food. Liquid protein extraction might involve only 10,000 acres, but such processing could be a suitable adjunct and could favorably impact the economics of the joint venture. The cellulosic fraction remaining after the protein fraction separation would likely require drying, but then could be used as fuel for the gasifier. 


\section{TASK 2. BUSINESS PLAN}

\subsection{Introduction And Background}

This business plan summary provides information for the organization of a joint venture to provide a biomass production capability and operate a combined processing and power plant facility that will generate electricity and produce a protein co-product for the animal feed market. This system uses alfalfa from a dedicated feedstock supply system (DFSS); namely, biomass material planted specifically for an energy production facility. The focus of this plan is to show how two products of this renewable, or sustainable, biomass production system can be supplied reliably and priced competitively to enable a viable business entity.

The concept was chosen because it could be done with a feedstock that has been sucessfully grown in NSP's service territory including the region surrounding NSP's MN Valley Generating Plant at Granite Falls, MN. Additional acreage of the crop would enhance the regions ability to continue progress towards achieving a sustainable agricultural. The knowledge base, expertise and production capability for producing the crop is well established in the region.

It is a crop that can be grown on a long term basis by a group of farmers through a closed-end cooperative arrangement (i.e., membership is offered only to producers). This co-op arrangement is typical of other successful co-op arrangements in the vicinity of the MN Valley plant, where the co-op carries on a value added processing and marketing function for the farmer. This closed end co-op arrangement, would also allow individual farmers the flexibility to transfer their production allocation ownership as they need.

The proposed cropping plan involves planting alfalfa in a seven year cycle with 4 years of alfalfa followed by 2 years of corn and one year of soybeans. This seven year rotation (AAAACCS) is in contrast to the often used current rotation system of corn and soybeans being continously alternated (CSCSCSC).

Farmers have indicated a strong interest in adding plant diversity in their cropping rotations to enhance preservation of the productivity of the land. The AAAACCS rotation accomplishes that objective. A perennial crop such as alfalfa will reduce soil erosion from wind and surface water runoff, as well as reduce the fertilizer, chemical and tillage inputs compared with conventional cropping systems. There are many tangible and intangible reasons for a farmer to grow more alfalfa, but it must first of all be economically attractive compared to the alternative cropping 
rotation systems. Farmers have indicated a net return from the AAAACCS rotation, equivalent to the net return from a conventional CSCSCSC rotation would be necessary for them to consider a change from one crop rotation system to the other.

Efficient conversion technologies are proprosed to extract the thermal energy from alfalfa stem material. Also, advantageous fractionation processes are used to efficiently separate protein material from fiber material to acheive high protein concentration in the leaf portion and low nitrogen, sulfur and ash concentrations in the stem portion. In addition, the use of economical low grade heat from the power production section can be used to convert the crude protein in the leaf material to high value by-pass protein. Further, at the.site.used in this feasibility study, i.e.,at an existing power plant site, there is a) room to install the equipment, b)access to the existing electric transmission grid and c) a highway and rural road network throughout the alfalfa production region to minimize the cost of transportation.

The gasification process chosen is the Institute of Gas Technology (IGT) RENUGAS ${ }^{\text {TM }}$ technology. This air blown, thermal gasification process has been sucessfully demonstrated in a two pilot plants. At one plant, sugar cane bagasse has been succesfully gasified, and the bagasse is a physically similar to the stems of alfalfa. The gasification process is ready for commercialization.

The hot-gas-clean-up (HGCU), Lo-Btu gas combustion, and combustion-turbine combined cycle (CT-CC) power island is a Westinghouse Electric Corp. design. The HGCU technology has been deomonstrated on clean coal projects and pilot biomass gasification tests. The Lo-Btu gas combustion technology is currently being validated in pilot studies.

The site selected for the study is NSP's MN Valley Generation Plant near Granite Falls, MN. This site currently has a $50 \mathrm{Mwe}$ coal burning plant with an adjacent transmission substation providing access to the transmission system. There is room on the site for the necessary additional equipment.

\subsection{Joint Venture Description}

A joint venture has been proposed to accomplish the initial technology transfer and long term operation of facility.The proposed team would consist of a utility entity, such as the NSP Generation arm of Northern States Power Company, as the project developer and the electric power producer; and three other participant groups. 
A closed-end farmer owned cooperative would manage the supply of biomass, operate the coproduct processing facility, and market the co-product. Another group consists of the process and equipment suppliers for those systems that require demonstration at a commercial scale. The third group consists of the University of Minnesota, the Electric Power Research Institute (EPRI), U.S. Department of Energy's National Renewable Energy Laboratory (NREL) and local, state and federal government agencies, to provide technical and/or financial assistance to accomplish the technology transfer required for the project. These team members have missions within their respective organizations that are compatible with their proposed role in the joint venture.

The project would be conducted in three phases:

PHASE I Team organization to respond to request for proposals for electrical capacity and cost-share/technology-transfer assistance.

PHASE II Establish design design basis information, finalize facility design and apply for facility permits.

PHASE III Construct facilities, develop the biomass shed and begin operation

Initially, the joint venture agreement would consist of an arrangement between an alfalfa co-op, the technology suppliers, and a utility entity to each own defined pieces of equipment placed on a common site, with the equipment of each party being designed to work together. Each party would also have designated responsibilities for operating and maintaining specified pieces of equipment. Each party would have procurement and/or marketing responsibilities for specific items such as feedstock, consumable materials or end products. The initial owners would share the net income from the venture in the same proportion as ownership. This organizational structure provides a way for the project to match the expertise and responsibility of the joint venture panners where it is in the best interest of the joint venture. The initial arrangement would allow the technology suppliers an option to sell their interests after the technology had been demonstrated to operate as proposed.

Inlew Congress extends the availibility of certain tax credits it is unlikely that such credits u ould the available for a project like this. The Sec. 29 credits are scheduled to end in 1996, although Congress was considering extending them in the fall of 1994. The utility might be able to use the IRS Sec 45 credits from the Energy Policy Act of 1992 for the generation of electricity from a closed cycle fuel arrangement, although the use of a co-product might make this concept ineligible. The Sec 45 credits are scheduled to end in July 1999, but the IRS would need to rule that a project underway by that date would make them applicable. Further, to the extent a project 
receives cost share from federal, state or local goverment sources, the tax credits are proportionately reduced

\subsection{Description Of Products}

\subsubsection{Electricity}

Electricity generated from biomass provides the utility an opportunity to communicate to customers about a locally produced source of energy and the intangible value of landscape protection that environmentally progressive projects like this bring. Product differentiation is not always used with traditional power plant fuels, but in this case it can be a very valuable addition to a utility public information program.

The fuel source, namely alfalfa stem material, is closed loop because the $\mathrm{CO} 2$ is removed from the atmosphere during photosynthisis processes of plant growth, and later in the process of gasification and combustion it is released back to the atmosphere. At some level of planning, this closed-loop characteristic may have an externality value of $8-18 \$ / M W h r$ (coal base load cost plus this amount would be the cost at which a renewable option would be considered comparable), according to the Minnesota Public Utility Commission (Order Establishing Interim Environmental Cost Values, Docket No. E-999/CI-939583, MN PUC).

Afalfa stem material used in this project must support a portion of the production cost of alfalfa. Therefore, it becomes important from an electricity cost, as well as an emissions viewpoint to use the material efficiently. The conversion technology selected for this project is an efficient gasification process as is the power production process. The overall efficiency for the use of the heat energy of the stem material is $38 \%$.

The supply arrangement proposed will support the base load nature of this plant. About $40 \%$ of the feedstock for the plant will be transferred directly to the plant soon after baling. The other $60 \%$ of the feedstock will be stored at the regional storage sites within a 50 mile radius of the plant for use at the plant at some other time during the year. Selection criteria for these storage sites will include accessibilty to enable feedstock to be delivered to the plant on a six day a week basis. Processing of feedstock will take place 24 hours a day, and there will be 4 days of stem material storage on site to provide a steady uninterrupted flow to the gasifier. 


\subsubsection{By-Pass Protein Co-Product}

Alfalfa is a well known crop in the Upper Midwest and many other regions of the country and the world. It is most often used as a forage crop, but it is also processed. The most common offfarm processing is producing de-hydrated alfalfa pellets. The co-product produced in this arrangement differs from a strict forage crop and is categorized as a mid-level protein. The heat treatment (roasting) that is applied converts the crude protein to by-pass protein, to allow a ruminant animal such as a dairy cow to use the protein more efficiently. This product uses fresh chop, or sun-cured alfalfa which is then dried and pelleted. Alfalfa has a well established reputation as an animal feed ingredient.

\subsection{Product Cost Analysis}

\subsubsection{Cost of Electricity Comparisons}

The information in Table 2-1 compares several different technologies with two ALFAGAS cases. The information on the technologies other than the ALFAGAS cases is from a report by EPRI;Strategic Analysis of Biomass and Waste Fuels for Electric Power Generation, TR-102773. These plants assumed a capacity factor of $80 \%$.

The cost for the first case is for a situation where the demonstration plant qualifies for federal or state government cost share is $1 / 3$ (other USDOE Clean Coal Program supported energy projects). The second ALFAGAS case is an estimate for an nth plant (i.e., mature technology) with the lower cost reflecting experience gained from building multiple plants. The ALFAGAS cases use a capacity factor of $85 \%$. The cost of electricity is influenced by the plant size, economic and financial assumptions used, and frame work used for evaluation. The data in Table 2-1 are not directly comparable because of the different bases used, but the COE values show the relative placement of COE for different technnologies relative to the ALFAGAS options.

\subsubsection{Co-Product}

In Table 2-2, the value in a feeding ration of by-pass protein has been shown to be $\$ 187.39 /$ ton for high corn and soybean prices (see Vol 1-Sec 7.5) produced from a leaf meal meal with $30 \%$ $\mathrm{CP}$ concentration prior to bypass treatment. The value of the co-product used for the base case calculations is for a 30\% CP concentration, but a lower corn and soybean meal price,closer to the assumptions used for the breakeven price analysis evaluation for production costs. The value of the bypass protein $\mathrm{ijs} . \$ 161.63 /$ ton at $8 \%$ moisture content $(\mathrm{MC})$. For leaf material at $15 \% \mathrm{MC}$, this translates to a value of $\$ 149.32 / \mathrm{ton}$. The value of the leaf meal fraction of alfalfa arriving at the facility is determined by the weight of the leaf material (@15\% MC) times the $\$ 149.32$ /ton amount. 
Table 2-1 Comparison of COE for Different Biomass Generation Options (from EPRI TR-102773, Except for ALFAGAS Data)

\begin{tabular}{|c|c|c|c|c|c|}
\hline TECHNOLOGY & $\begin{array}{l}\text { Net } \\
\text { Capacity } \\
\text { MW }\end{array}$ & $\begin{array}{l}\text { Net Heat } \\
\text { Rate, } \\
\text { Btu/kWhr }\end{array}$ & $\begin{array}{l}\text { Total Capital } \\
\text { Requirement, } \\
\$ / \mathrm{kW} \\
\end{array}$ & $\begin{array}{l}\text { Levelized COE, } \\
\text { cents/kWhr }\end{array}$ & $\begin{array}{l}\text { Plant life, } \\
\text { development } \\
\text { level }\end{array}$ \\
\hline Wood-fired stoker & 50 & 13,894 & & 8.1 & 30, nth \\
\hline Wood fired FBC & 50 & 13,864 & 2,085 & 9.0 & 30 , nth \\
\hline WTETM Boiler & 100 & 10,664 & 1342 & 5.6 & 30, nth \\
\hline WTE' boiler & 50 & 10,661 & 1,723 & 6.6 & 30 , nth \\
\hline Wood GCC & 100 & 12,365 & 2,466 & 9.7 & 30 , nth \\
\hline Advanced wood GCC & 100 & 9,751 & 2,128 & 8.0 & 30, nth \\
\hline $\begin{array}{l}\text { ALFAGAS } \\
\text { ( } 1 / 3 \text { invest. cost share) }\end{array}$ & 75 & 8910 & $\begin{array}{l}1258 \\
\text { (after cost share) }\end{array}$ & $\begin{array}{l}6.5 \\
\text { (with cost share) }\end{array}$ & 15, demo. \\
\hline $\begin{array}{l}\text { ALFAGAS } \\
\text { (nth plant @ } 80 \% \text { of } \\
\text { demo. project cost) }\end{array}$ & 75 & 8910 & $\$ 1543$ & 6.6 & 15 , nth \\
\hline
\end{tabular}

Note (EPRI data escalated from1991 to1994; ALFAGAS data in mid 94\$)

Table 2-2 Value Of Alfalfa Leaf Meal in Dairy Rations

\begin{tabular}{|l|c|c|}
\hline \multicolumn{1}{|c|}{ Leaf Meal Characteristics } & \multicolumn{2}{|c|}{$\begin{array}{c}\text { Corn Grain and Soybean } \\
\text { Meal Price Levels } \\
\text { High }\end{array}$} \\
\hline Meal crude protein level, \% & 30.00 & 30.00 \\
\hline Value with no by-pass treatment, \$/ton & 123.36 & 106.40 \\
\hline Value with bypass treatment, \$/ton & 187.39 & 161.62 \\
\hline
\end{tabular}

The market for mid level protein is large and the production of 321,000 tons per year from a plant of this size is small compared to the 7.2 millions tons the U.S. exported in 1993, and the large approximately 30 million ton per year domestic market.

\subsection{Market Analysis}

\subsubsection{Biomass Electricity Generation Market}

The 1492 Energy Policy and Conservation Report by the Minnesota Department of Public Sernse reports that the State's utilities project that electricity consumption will continue to grow in the residential, commercial and industrial sectors. Further, the Report states that the 1991 Minnesota Legislature required that electric utilities demonstrate that increased demand cannot be be satusfied by renewable resources before the utilities are allowed to construct a more traditional fueled power plant. These provisions will increase the consideration of renewable energy sources such as biomass based options, and serve to increase the market for these options. 
The USDOE in it's 5 Year plan for Biomass Power Program projects biomass fueled capacity to increase from 6500Mwe in 1992 to $25,000 \mathrm{Mwe}$ by 2010. This expansion in the use of biomass feedstocks for power production, will require that an abundant and reliable supply of low cost biomass feedstock is available. USDOE believes a window of opportunity exists for accelerating the expansion of biomass power in the U.S. energy mix because of:

- the need for rural revitalization and job creation;

- concerns regarding global climate change;

- new Clean Air Act ammendents

- increasing waste disposal costs

- the desire to improve international industrial competitiveness

- growing worldwide energy demand

- energy security issues.

The above discussion points are focused on the energy market demands from a strategic view, but for this particular concept the market will also be influenced by the demand for the coproduct. Although, the economics of this business venture are focused on one co-product, the protein from alfalfa can be extracted in different forms. As higher value co-products are identified, the opportunity to lower the cost to generate electricity from the remaining cellulosic fractions can be examined. Other biomass feedstocks may find similar market niches where use of the plant extracts and the remaining cellulosic fractions can be combined together in a viable business venture. As higher valued uses can be found for variations of the processed leaf material, the utility as well as the alfalfa co-op will have enhanced returns which can be returned to investors or customers.

The proposed long term joint venture arrangement in this project would be between a utility entity and a producers (closed-end) co-op. A co-op would be able to raise equity from its members and debt from co-op banks. Although this does not directly influence the cost of electricity, this allows the utility entity to use its capital resources in a way to take advantage of this environmentally progressive project.

\subsection{Financial Analysis}

Financial projections for this concept have been developed from the base data that has been developed from other sections of this report. Table 2-3 summarizes the effects of cost share and tax credits. The capital cost of the gasification and power islands was developed from the design bases in Vol. 2. The direct costs of the processing, gasification and power islands include equipment, structures and construction activities. No cost for land is included because an 
existing site owned by NSP was considered for the feasibility study. In addition to the direct costs, indirect costs for permitting, facility engineering, and project management have been included. The capital cost for the facility is shown in Table 7-1, Volume 3.

Table 2-3 Summary Of Cost Share And Tax Credit Influence

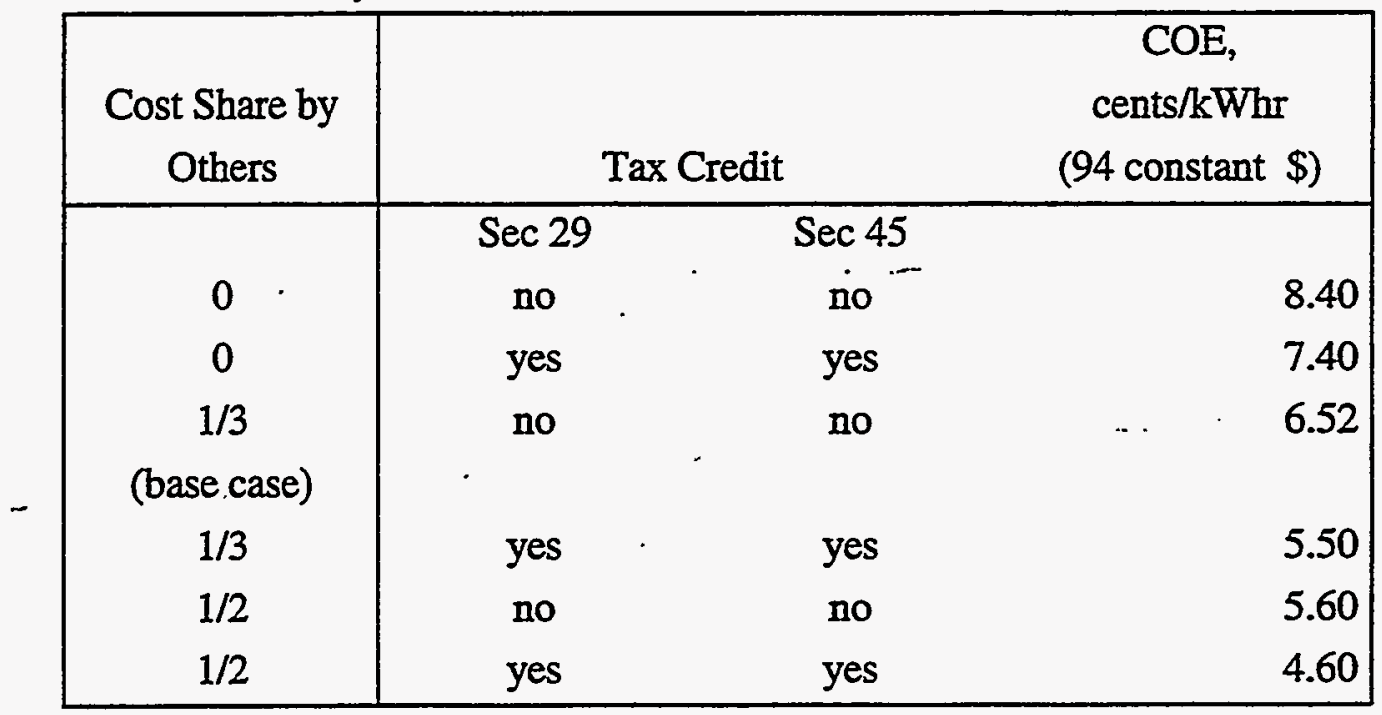

The base case assumes 50\% ownership each by the utility and the co-op. It assumes one-third cost share by USDOE/NREL or others, which results in an investment (including AFUDC for the utility portion or interest on construction funds for the co-op) of either the utility or the co-op equal to the cost share. Since the cost share does not require an interest during construction component, the total cost for the project is less by.that amount than the total project cost without cost share.

The target cost for alfalfa is set at $\$ 67.44$ per ton (15\% MC and prime grade alfalfa material). This is the value from Volume 1 ( $\operatorname{Sec} 4.2$ ), where the AAAACCS rotation system provides an equivalent (as defined in that section) net return to that of producing, storing, transporting, accomodating shrinkage, marketing and selling corn and soybeans in a CSCSCSC rotation.

The farmer provides an equity investment via the co-op at a \$acre amount that will raise $1 / 2$ the equity needed by the co-op (1/4th the needed investment cost after cost share). For the base case it is $\$ 127$ per acre. 
The proforma assumes $50 \%$ debt and $50 \%$ equity, a slight departure from a typical utility split such as NSP's $52 \%$ debt and $48 \%$ equity structure. The discount rate of $8.54 \%$ reflects the cost of debt and the allowance for a return on rate base equity (in this case 11.5\%).

The base case results in a cost of electricity (COE) of 6.52 cents per $\mathrm{kWhr}$ on a constant dollar basis (no inflation adjustment) for the condition with the co-product having a value of $\$ 161.63$ $\$ /$ ton (at $8 \%$ M.C.). This COE is a result of achieving the necessary payment to the farmer to meet the $\$ 67.44$ /ton target for producing the alfalfa and providing a return on the investment the farmer makes in the co-op. The leaf meal market exposure requires a return on equity that reflects the possibility of market price variability of a portion of the revenue stream. An annual average return over the 15 year project life of $11.5 \%$ on initial equity value selected for the analysis.

The risk of new technology is managed by the use of government cost share and requesting the conversion technology suppliers to hold an equity position until the technology has proven reliable, or warrant the systems at the start. It is anticipated that the new technology suppliers would take an equity position in the project during the early years, with an agreement to be bought out upon achieving reliable operation of the new technology equipment. This pre-defined buy-out would probably take place in the first $3-5$ years.

\subsection{Business Strategy}

This joint venture could be initiated after consideration of a) the requests for proposals issued by the USDOE for pursuing the commercialization of the new conversion technologies; $b$ ) the solicitation by a utilitiy for introducing biomass based electricity generation on a utility scale; and c) the response by farmers to become involved by adding plant diversity improvements to their crop rotation systems. In addition to the cost share that is anticipated through the USDOE/NREL RFP process, other sources of cost share or cost stabilization (e.g., non-escalating property tax) could be explored. Discussions with local government units on property tax levels the project can absorb and the taxing jurisdictions can accept would need to be determined. There would need to be discussions with USDA organizations to determine how the new crop rotation systems would be considered within the existing support programs for corn and Conservation Reserve Program.

One of the differences of the power generation facility from a traditional fossil fueled facility is the necessity to accomodate the weather influence on the fuel supply and the market influence on the value of the processed leaf material. The responsibility for supplying a given quantity of stem 
material would rest with the co-op. But in the event of a short-fall of stem material from weather conditions, back-up fuel of natural gas could be used. The difference in price of stem vs. natural gas fuel would need to be defined in advance. Conceivably, a short fall of alfalfa feedstock could raise the value of leaf meal to overcome any increase in cost from natural gas purchase. Also, in years where drought might be severe, alfalfa would likely be in short supply, but other biomass might result from crops not being harvested for grain.

\subsection{Project Development}

A schedule of activities has been developed to respond to the anticipated activities described in the business strategy above. This concept could likely provide a competitive response to these two RFP's. Responses will probably be due 120 days after the RFP's are issued. The schedule summary, Figure 2-1, shows the anticipated activities. By the end of 1995 agreements could be in place between the joint venture team and both USDOENREL and the NSP resource planning group.

There are several key design bases that need to be established very early in the project. Process validation tests can be conducted at existing facilities to determine the design bases, and the results will provide the details for business option evaluations, engineering design activities and permit application planning.

The biomass shed development needs to be done in sufficient time to provide stem material for the the startup and operation of the power plant. In addition, it would be desireable for the market for the leaf meal to be fully established. To allow for development of the by-pass protein market for this alfalfa based feed supplement, the shed is assumed to be developed early. Prototype separation and meal processing facilities are assumed to be financed outside the project. Sales of processed leaf material and stem material (as a boiler fuel or in some other application) would provide the early income to support this venture. 


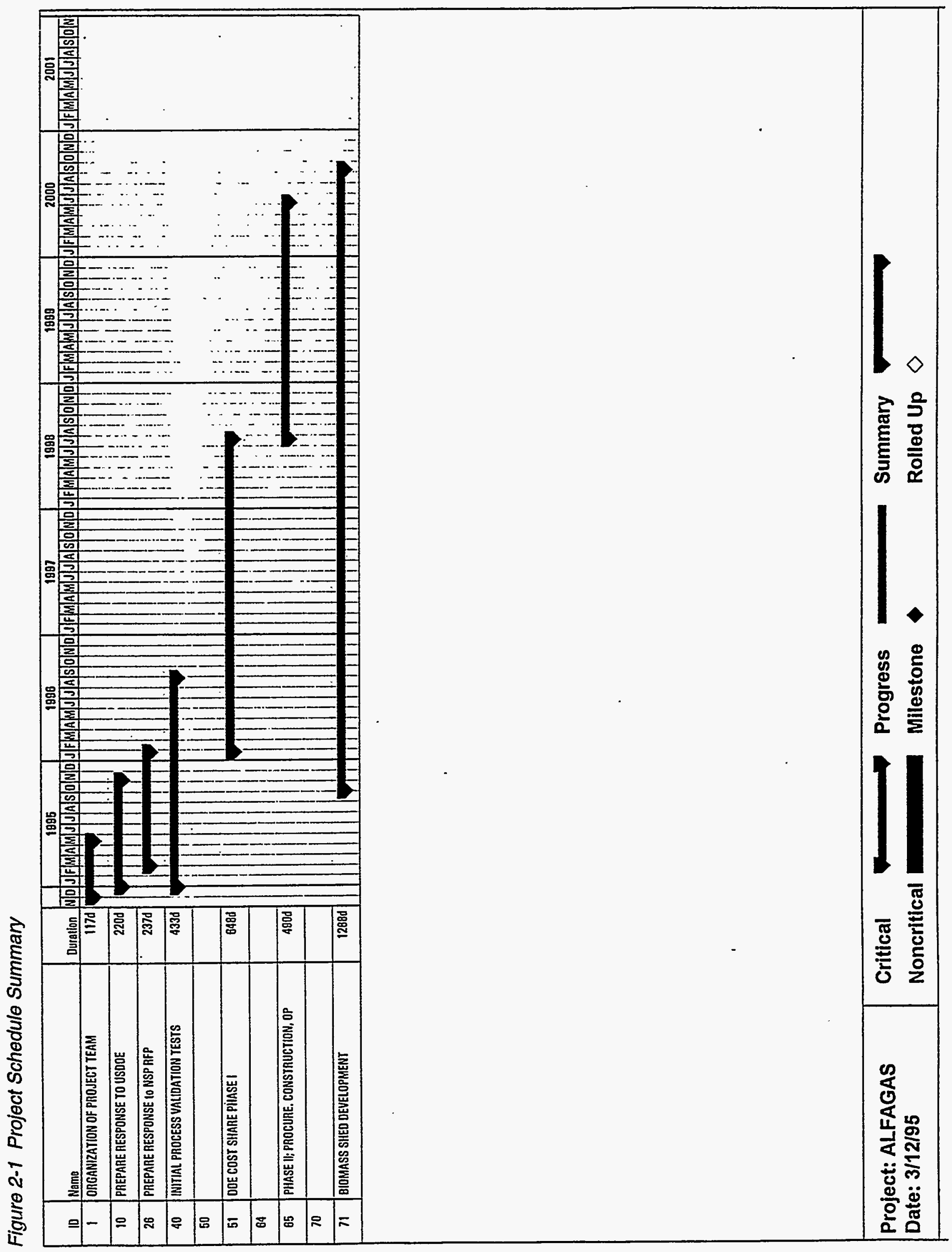




\section{TASK 3. THE DEDICATED FEEDSTOCK SUPPLY SYSTEM (DFSS)}

\subsection{An Alfalfa Based DFSS}

A Dedicated Feedstock Supply System (DFSS) must be a crop that can be successfully produced in an economical and environmentally sustainable way in the quantities required to support electric energy production. Alfalfa can be produced in Southwest Minnesota and meet those qualifications. Currently, alfalfa is grown in rotation with corn, soybeans, and other crops in the region. It's use can be expanded to provide a stable biomass fuel supply as well as serve as a crop rotation element that is compatible with a other cropping systems carried on by-farmers in the region. A DFSS is the successful combination of approaches to addressing the technical, economic, and environmental issues of concern to farmers, landowners, and the rural community

Minnesōta farmers currently produce over 6.9 million tons of alfalfa hay per year, the fourth largest production level of alfalfa in the country. However, alfalfa acreage covers less than $6 \%$ of Minnesota's total cropland (Minnesota Agricultural Statistics 1992). The expansion of the production of alfalfa for energy is a major new market, and at the same time, allows farmers the benefits from including alfalfa in traditional rotations. These farmers would be motivated to start producing or increase their production of alfalfa to increase profitability, and reduce risk through diversification as well as other tangible economic and environmental benefits.

Alfalfa grown for energy generation and a high protein animal feed will utilize the existing capabilty and expertise for production, but the end result will be significantly different from alfalfa produced strictly as a forage feed. Alfalfa feedstock would be produced by experienced, operating farmers within about a 50 mile radius of the processing/power plant. Existing farm machinery is available from a variety of suppliers for the production and harvesting of alfalfa.

Alfalfa would be processed, much like com and soybeans are processed, to produce multiple products. Although yield is important in this concept, efficient use of both the leaf and stem fractions of alfalfa is key to the economic sustainability of the venture. The cost of production of the biomass is supported by revenue from two products requiring neither to carry the entire cost of production.

The proposed approach in this study is a utilization of a dedicated energy crop that increases the sustainability of an agricultural production system. Alfalfa provides real benefits for other agricultural crops in the rotation. These benefits result from the inclusion of a perennial 
(nitrogen-fixing) legume in the rotation. The need for external inputs of fertilizers and fossil fuels are reduced while distinct environmental benefits including reduced soil erosion, improved soil tilth, increased soil organic matter levels, and reduced potential for nitrate leaching are realized.

The use of a closed end co-op to manage the alfalfa production and the leaf meal processing and marketing meets the farmers desire to have value added locally, and in a way the farmer benefits directly from an investment in co-op ownership. Also, the community benefits directly from the increased local economic activity.

Bringing an alfalfa based DFSS up to full production to supply biomass to the electric generation facility can be done during the same time period as the facility is being constructed. Thus fuel can be ready to support the generation facility start up and ramp up to full operation. About 2000 farmers would be required to provide the 183,000 acres of alfalfa needed annually to mantain the operation of the electricity generation plant at its full load of $75 \mathrm{MW}$. The acreage would likely come from existing corn and soybean production or from Conservation Reserve Program (CRP) lands. Alfalfa production would be ramped up during a three year period prior to power plant full load operation. Stem material could be processed and used for co-firing with coal at the existing power plant, or other regional power plants, or used as a constituent in the animal feed produced by the processing plant. The processing plant would be started and ramped up earlier than the power plant.

\subsection{Sustainability}

A sustainable biomass energy production system must provide viable economic returns for farmers and provide an incentive to continue to produce an adequate amount of fuel for the power plant energy needs. A sustainable biomass energy production system must also fulfill the social needs of farm families and rural communities, and be environmentally sound. When included as a major component in conventional agricultural rotations, alfalfa addresses and meets these economic, social, and environmental concerns. Thus alfalfa is a benchmark feedstock for sustainable biomass energy production.

Alfalfa, as a crop-rotation complimentary biomass energy plant, provides a new economic opportunity for farmers. However, unlike switchgrass and hybrid poplar, alfalfa can be easily integrated into rotations with grain crops on prime agricultural land. This is especially important at this time in history when traditional American agricultural commodity markets are declining. USDA forecasts that within the next 40 years 150 million acres of cropland, now in production, 
will not be necessary to supply anticipated global demand for American agricultural commodities.

Alfalfa protects cropland that is susceptible to soil erosion. The root system and unharvested top growth of alfalfa protect the soil from wind and water erosion year round conserving the farm's greatest resource, top soil. Reduced soil erosion reduces non-point source pollution of lakes and rivers. Allfalfa's deep tap roots remove nitrates from deeper soil profiles than do annual crops, thereby also reducing the potential for nitrate contamination of groundwater. The deep tap root system that develops over a four year growing season ( as much as $15 \mathrm{ft}$. deep) also helps improve water infiltration and soil tilth development, both of which help reduce the soil erosion pressure.

Alfalfa and other perennial legumes, unlike switchgrass and hybrid poplar, obtain nitrogen directly from the atmosphere (nitrogen fixation) and do not require nitrogen fertilization. Additions of fixed nitrogen to the soil from an alfalfa crop are estimated to exceed $50 \mathrm{lbs}$. of N/Acre/year, thus allowing a standard nitrogen credit to be given to crops following alfalfa in the rotation. This credit significantly reduces nitrogen fertilizer inputs, a major farm expense. Further, alfalfa is extremely important in the nitrogen cycle in the North Central Region of the US. Nitrogen fixed in the soil does not move into ground water supplies as do nitrate forms of mineral fertilizer. Alfalfa as a deep rooted perennial crop also increases the availability of subsoil nutrients for subsequent crops in the rotation by moving these to higher soil horizons.

The Minnesota River runs through Granite Falls on its way to the Mississippi River at St. Paul, MN. High-input agricultural production practices contribute to pollution of rivers, lakes and streams and also threaten ground water supplies in the region. Ground water in the area is generally classified as medium in terms of susceptibility to contamination. Many farm wells in the region are contaminated with high levels of nitrates. The high level of non-point source pollution of the Minnesota River is a major concern in this region and for the state. Buffer strips of perennial crops, such as alfalfa, along the river valley are envisioned as an important contribution by production agriculture to reduce the contamination of this major tributary of the Mississippi.

Alfalfa and other perennial crops in the rotation reduce certain weed, insect, and disease populations. Pesticide applications will be reduced both on crops following alfalfa but also on the alfalfa crop itself as the need for pesticide applications on established alfalfa stands are minimal. A particular soil pest, the soybean cyst nematode, which causes major yield reductions 
in soybean crops grown in areas where the nematode population is high, is controlled by rotation through alfalfa.

Alfalfa improves soil structure and increases soil organic matter levels. Corn yields following alfalfa are increased by an average of $15 \mathrm{bu} / \mathrm{A}$, if moisture is not a limiting factor. This (nonnitrogen related) yield increase is attributed to improvements in soil structure (Volume 1(10.2)). Additional benefits of growing alfalfa are an increase in water infiltration rates (that help prevent surface runoff) and increased soil biological activity.

Although the economics for this feasibility study are based on a three harvest per season plan, it is quite plausible that, with new varieties now being developed, a two harvest system would have additional advantages for wildlife survivability. Further a move to a two harvest system on a large scale for biomass energy production has the potential to provide major benefits for wildlife. The impact of the alfalfa biomass crop on wildlife is largely determined by harvest management. If alfalfa harvest is delayed until later in the the nesting season (alfalfa harvested strictly for forage value must be cut sooner) a dramatic increase in game bird populations and other wildlife species may be achieved.

A detailed analysis of the energy balance for the proposed project was done. Energy input:output analysis indicates the conversion of alfalfa to electricity results in a highly positive energy balance (1:3). The ratio of energy in to energy out is critical in determining the overall system efficiency for biomass energy production. Energy balances for the two different crop rotations studied (DFSS and corn-soybean) indicate that the DFSS rotation generates more gross energy and more crude protein per acre with lower energy inputs than a traditional corn-soybean rotation.

\subsection{Alfalfa Production}

Approximately 680,000 tons per year of alfalfa feedstock are required to meet the design capacity for the particular combustion turbine that was chosen for the study. The leaf to stem fractions of the feedstock is predicted to be $47 \%$ leaf and $53 \%$ stem (approximately 320,000 tons of leaf and 360,000 tons of stem). The gasifier requires 1000 tons per day of stem material to produce enough Lo-Btu gas to fully load the selected Westinghouse 251B12 combustion turbine. The feedstock could be delivered year-round to the facility located at an existing NSP power plant in Granite Falls, MN.

The biomass production area (biomass shed) was shown in an earlier section as Figure 1-1. The biomass shed as defined for this study is the area within a 50 mile radius of Granite Falls, 
Minnesota. This region in southwestern Minnesota was originally grassland prairie. Significant areas are tiled. Annual rainfall in the shed averages between 24 and 28 inches. The soils in the shed are generally neutral to alkaline in $\mathrm{pH}$, high in calcium, magnesium, and potassium, medium to high in organic matter, medium in nitrogen supply capacity, and low in phosphorus. Water permeability is often slow in many of the heavier-textured soils and water holding capacity is high.

Farmers in southwestern Minnesota depend primarily on cash crop production agriculture. The farmland within the counties touched by the 50 mile radius circle (Table 3.1) currently produce $2.8,2.6$, and 0.34 million acres of corn, soybeans, and alfalfa, respectively. The size of the average farm in the shed is 580 acres. The shed currently produces 1.4 million tons of alfalfa annually. This level of production, in the 21 counties touched by a 50 mile circle around Granite Falls MN, is two times more alfalfa biomass than what is required for the biomass energy production facility. An increase in dedicated alfalfa production of about 180,000 acres is anticipated to supply the biomass energy processing plant, and the additional acreage would likely come from the land currently in corn and soybeans. Determination of the overall size and shape of the biomass shed will be determined by climate, soil, cropping patterns, wildlife benefits, and economics.

Alfalfa yields (Table 3-1) in southwestern Minnesota around the Granite Falls plant site are about 4 tons per acre and are suitable for for sustainable biomass energy production. The lowest yield in the thirteen unique production regions, discussed, is $3.8 \mathrm{~T} / \mathrm{A}$, and this value has been used to estimate the number of acres required for production.

Benefits from including alfalfa in the rotation include: increased yield from other crops in the rotation, reduced external inputs of nitrogen, lower overall production costs (fossil fuels inputs), and distinct environmental benefits. Environmental benefits include reduced soil erosion, improved soil tilth, increased soil organic matter levels, reduced potential for nitrate leaching, and a reduction in diffuse source pollutants. .

Alfalfa and other perennial crops included in agricultural rotations reduce farmers' spring and fall workload compared to the planting and harvesting of annual crops. A farmer has interest in distributing work load away from peak demands of annual row crops and a three harvest system improves on that aspect compared to the typical four harvest system commonly used now. With the possibility of a two harvest system possible the situation could improve further. This will 
improve the total efficiency of the farming operation and add a degree of security during growing seasons when planting or harvest operations are threatened by weather conditions.

Alfalfa is cut, sun-cured, and baled into large round bales. Contracted alfalfa biomass producers would deliver their crop to regional storage sites in the biomass shed. The transportation and storage system has been designed so that most producers have less than 5 miles to travel to a remote storage site. Alfalfa would be weighed and tested for quality at the remote site. During the growing season, about $40 \%$ of the crop would be direct-hauled from remote storage by the cooperative or joint-venture to the processing plant. The remaining $60 \%$ of the crop would be placed in storage under plastic covers and/or in steel pole buildings.

Table 3-1 Crop Acreages And Alfalfa Yield By County For The Biomass Shed

\begin{tabular}{|c|c|c|c|c|c|}
\hline County & $\begin{array}{r}\text { Corn } \\
\text { (acres) }\end{array}$ & $\begin{array}{l}\text { Soybeans } \\
\text { (acres) }\end{array}$ & $\begin{array}{l}\text { Alfalfa } \\
\text { (acres) }\end{array}$ & $\begin{array}{l}\text { Alfalfa } \\
\text { (tons/acre) }\end{array}$ & $\begin{array}{l}\text { Alfalfa } \\
\text { (tons) }\end{array}$ \\
\hline Big Stone & 53330 & 88700 & 5900 & 4.3 & 25400 \\
\hline Brown & 133500 & 133200 & 14100 & 3.2 & 45100 \\
\hline Chippewa & 120000 & 121600 & 4600 & 4.4 & 29900 \\
\hline Cononwood & 142300 & 171500 & 10200 & 4.2 & 42800 \\
\hline Lac Qui Parle & 120100 & 153200 & 6800 & 4.4 & 29900 \\
\hline Luncoin & 86500 & 72500 & 16900 & 4.0 & 67600 \\
\hline Lyon & 164800 & 153200 & 14200 & 4.6 & 65300 \\
\hline Kandiyohi & 145800 & 99800 & 22700 & 4.6 & 104000 \\
\hline Mceker & 112800 & 83700 & 21000 & 4.7 & 98700 \\
\hline Meleod & 82400 & 84500 & 19400 & 4.7 & 91200 \\
\hline Murray & 157400 & 161000 & 11000 & 4.0 & 44000 \\
\hline Nicollet & 104300 & 97400 & 8600 & 4.1 & 35300 \\
\hline Pipestone & 107600 & 79600 & 13600 & 4.5 & 61200 \\
\hline Pope & 91300 & 56300 & 23700 & 4.2 & 99500 \\
\hline Resuood & 208800 & 224200 & 8900 & 4.3 & 38300 \\
\hline Renville & 209300 & 234400 & 9700 & 4.5 & 43700 \\
\hline Sible! & 116300 & 119800 & 14800 & 4.5 & 66600 \\
\hline Stearns & 234600 & 41500 & 90900 & 4.0 & 363600 \\
\hline Stevens & 91199 & 105200 & 5100 & 4.4 & 22400 \\
\hline Suith & 138600 & 124200 & 6400 & 4.0 & 25600 \\
\hline Yellow Medicine & 160800 & 170300 & 7400 & 4.4 & 32600 \\
\hline Totals & 81,600 & $2,575,800$ & 335,900 & 4.24 & $1,423,000$ \\
\hline
\end{tabular}


Location of the alfalfa separation and co-product processing facility integrated with the power plant offers the potential to use steam for alfalfa processing. For example, steam will be used to process leaf meal to increase its feed value, and hot air from the power plant exhaust system will be used for a part of the fuel drying heat requirement

\subsection{Production Economics}

For the alfalfa biomass project concept based at Granite Falls, Minnesota, pro forma farm budgets were used to compare the net returns to farmers of rotations including alfalfa versus traditional corn-soybean rotations. Pro forma budgets were used as a means to portray alternative business plans. To make comparisons all streams of revenue, value, and costs, whether explicit or latent must be accurately and systematically identified and portrayed. All activities such as tillage, planting, harvest, etc. needed to produce various crops must be included with their costs being assigned to the proper crop year. In the case of the "biomass energy" rotation, or DFSS (Dedicated Feed Stock Supply) the sequence AAAACCS was assumed, which stands for a seven year rotation with four years of alfalfa followed by two years of corn, and then one year of soybeans after which the sequence repeats.

A number of factors govern the inherent productivity of soils in a given region. Soil productivity combined with economic forces that affect demand for land resources determine land value. Thirteen unique production regions have been described for the purpose of developing pro forma budgets for alfalfa biomass production (see Figure 3-1). Budgets display a relative advantage or disadvantage of an alfalfa biomass rotation versus a conventional com-soybean rotation. Specific pro formas were generated for each of the thirteen production regions to accurately portray each region's crop yield potential and cash rent environment. It should be emphasized that comparisons are between the multi-year rotations, not the individual crops. The average breakeven price for alfalfa in the biomass shed is calculated at $\$ 67.44$ per ton. This represents the total cost of feedstock production, and how much is allocated to stems or leaf material is more appropriately done from the joint business venture proforma than the alfalfa production proforma.

Exogenous changes, such as significant alfalfa yield increases (perhaps due to future alfalfa breeding) elimination of feed grain deficiency payments, increase in corn and soybean prices were modelled. These other analyses were also performed strictly upon CER score, which reflects the inherent productivity of soils. CER's are an index developed for Minnesota soils that measures relative net income of soils based on typical rotations and crop mixes found on different soils. Rents were assumed to be zero for these other analyses at all CER's in order to demonstrate how effects can vary for soils across the range of relevant productivities In this manner it was possible to 
determine the effects of exogenous changes on breakeven alfalfa prices. These analyses showed an yield increase of $20 \%$ could lower the breakeven price $10 \%$; a loss of corn deficiency payments would lower the breakeven price of alfalfa by $3 \%$; or an increase in corn and soybean prices of $20 \%$ would raise the breakeven price by $8 \%$.

\subsection{Biomass Supply Curves}

A supply curve relates an offered price to an expected production level. The critical analysis variable is the ratio of net return of the DFSS to the continous C-S rotation. Supply curves for alfalfa biomass production were developed from estimated farmer adoption rate as a function of net economic return ratio (a return from a seven year continous corn-soybean rotation, i.e.,CSCSCSC, compared to the return from one with 4 years of alfalfa in it, i.e., AAAACCS). An adoption rate schedule was defined for a range of net return ratios (e.g., for one point on the curve, a DFSS:C-S net return ratio range of 1.0-1.1 results in an adoption rate of $10 \%$ of the land that could potentially grow alfalfa). The DFSS production potential for each of 13 specified soil regions was taken as $80 \%$ of the productive land. Thus for the breakeven price of $\$ 67.44 /$ ton for alfalfa, the adoption rate is $10 \%$, and the total tonage that could be produced is 840,000 tons (see Fig. 3-2) The facility needs 680,000 tons per year, therefore sufficient quantities of feedstock are predicted to be available.

However, the breakeven price is only one element received by the farmer that would support the adoption rate values asserted. Because the project would want feedstock supply assurances over the life of the project, it would be necessary to secure the additional element of a long term agreement. A long term agreement between the co-op and the farmer to supply alfalfa would be in the interest of the farmer because it substantially reduces the exposure of price variability typical of commodity markets and in this concept, risk is further reduced because the co-op assumes the risks of feedstock storage, transport, processing and leaf meal marketing and sales. It is this element that would give the farmer high interest in participating in the co-op, and a suitable reason for participating if alfalfa could sold at the breakeven price.

At the breakeven condition, the farmer would get paid about $97 \%$ of the target price in a series of periodic pre-processing payments throughout the year. The business venture takes title and responsibility for the alfalfa at time of harvest and manages the storage, transportation and shrinkage and associated cash flow for these operations. The business venture takes on management and financial responsibility for processing, marketing and sale of the leaf meal product. The remaining $3 \%$ of the breakeven price and an opportunity rate of return of $5 \%$ on the 
farmers investment in the co-op, is paid out as the growers share of the net income from the business.

The initial co-op invesment is available to the farmer at the end of the 15 year life of the plant from the depreciation reserves. The participation in the co-op would pay an average annual $11.5 \%$ return on the farmer's initial co-op investment which is equivalent to covering the small remaining portion of the breakeven price (i.e. 3\%) not received as a preprocessing payment and a return on the investment in the co-op at an opportunity rate of $5 \%$. In effect, the responsibility for the risk of feedstock storage, transportation, processing, and leaf meal marketing sales is transferred from the the individual farmer to the collaborative effort of the co-op. The joint business venture (for the base case situation) has purchased the alfalfa at the edge of the field from the farmer at $\$ 67.44 /$ ton, covered the cost of storage and transportation at $\$ 11.27 /$ ton, covered shrinkage at $\$ 2.06 /$ ton, processed the alfalfa to produce a leaf meal fraction for sale and stem fraction for use in electric energy production at $\$ 39.51 /$ ton, paid the for the farmer's investment in the co-op at \$1.73/ton with revenue averageing \$123.47/ton. Risk reduction and value added have been addressed in this concept which would contribute to the acceptability to the farmer of the $10 \%$ adoption rate criteria for the breakeven net return ratio situation. 


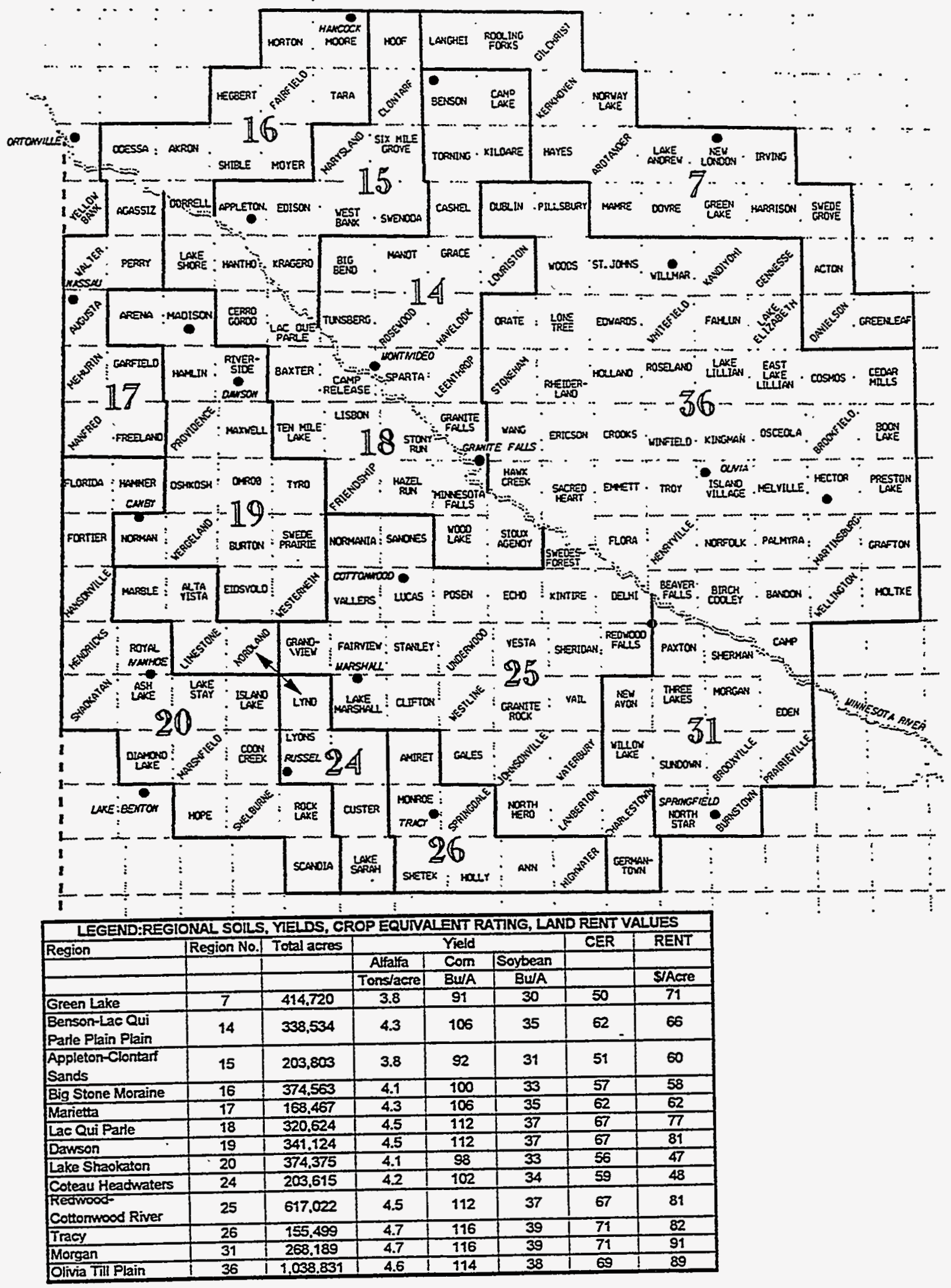


Figure 3-2 Baseline Regional Biomass Supply Curve and Adoption Rate Function

Regional Biomass Supply Curve (base scenario).

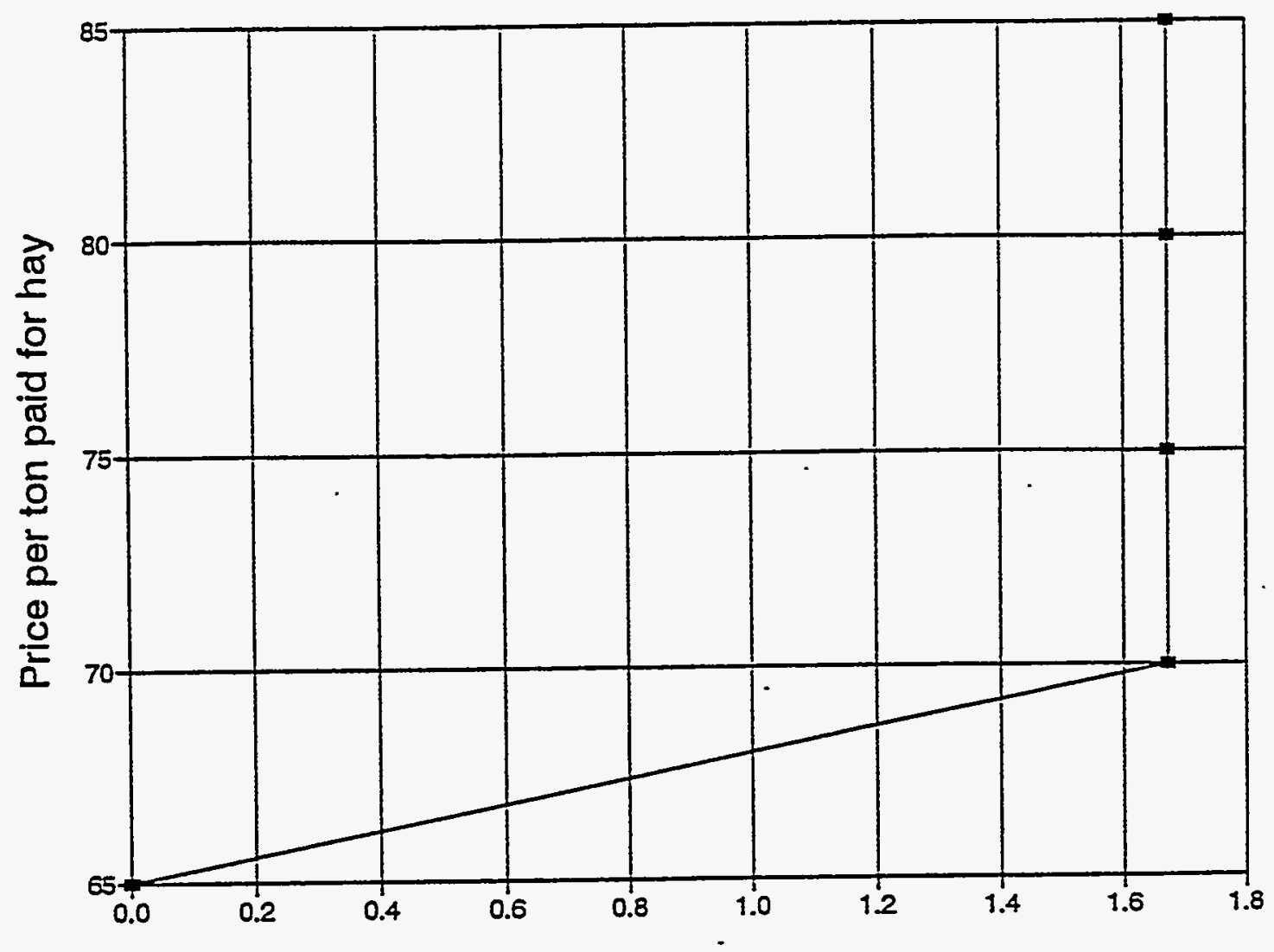

Tons of Alfalfa Sold in the Region

(millions)

Baseline DFSS rotation adoption rate.

ADOPTION RATE

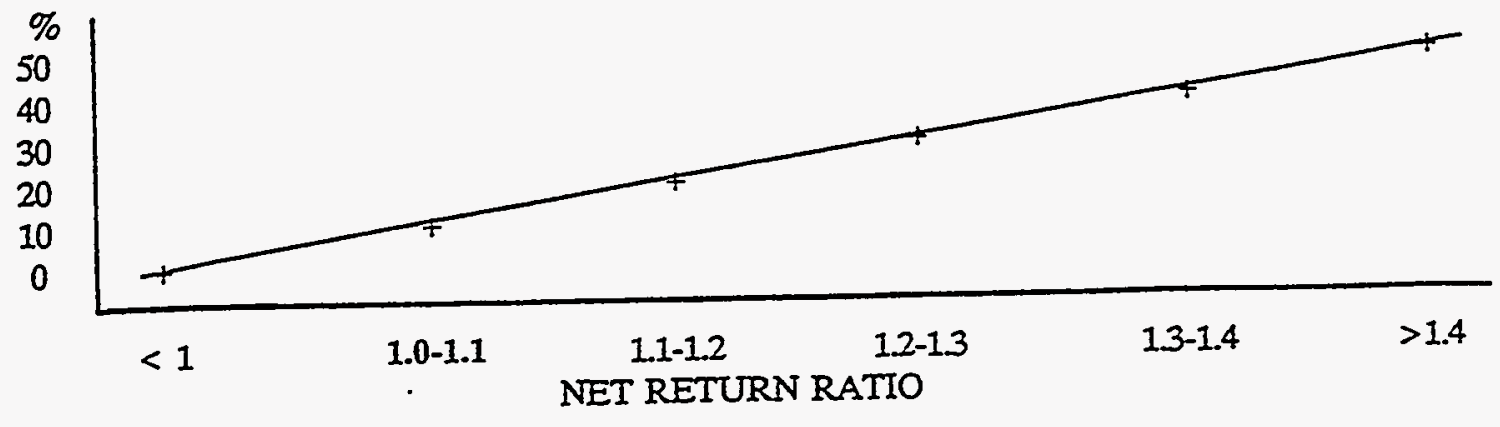




\subsection{Alfalfa Storage, Transportation and Processing}

The practicality of using biomass as an energy source is often constrained by the cost of handling, transportation and processing of the biomass. These constaints are often a result of low bulk density of the biomass material, either from the high mosisture content of the material, or the inherent low density of the energy bearing cellulosic material. This concept minimizes the influence of these typical constraints by using sun cured material where the moisture has been partially removed, packaging the material if a big, round bales and having nearly every step of processing beneficial to the two products thus neither product has to bear the entire cost of the processing step.

This concept uses the round bale system packaging approach, to increase the bulk density and to allow for mechanization during handling operations, and efficient use of a truck system for transport of the material. Since the alfalfa is sun cured in the field prior to baling, the moisture content is reduced from $65-70 \%$ to $15-20 \%$.

Transportation costs from the field to a remote storage site are considered to be the responsibility of the producer. An allocation of $\$ 3.93$ per ton has been included in the proformas to move the material from the field to the regional storage site. Transport could be done using wagons, trucks. or special hay hauling equipment. After arriving at the regional storage site bales are cored and sampled. Grower's name or identification number, alfalfa weight, quality, and moisture are recorded by a computerized data collection system.

Hariest dates initiate the flow of alfalfa from fields to storage sites. Alfalfa may be harvested as early as late May and as late as early October. This report utilizes data for a three-cut harvest systems. where harvest would take place usually from June 1 to September 1. During the harvest penod all of the baled alfalfa would be moved from the fields to the regional storage site. Bales recerved at the site would be weighed, tested for mosisture content and protein content( near infra-red spectroscopy used to obtain a nitrogen signature indicative of protein), and the results tabulated is to quality, location produced and grower. These are typical of the type of meisurements currently being conducted at hay auctions in the region. Once evaluated the bales would either be stored at the regional site or shipped to the plant site. The cost for material stored at the site under a plastic tarp has been used in this analysis, although costs for storage in a building or with no protection have also been evaluated. 
Production, transportation, and storage are linked by the dry matter losses that occur during storage. Three basic storage options were analysed: 1) a "no cover" option where bales are stored outdoors without protection and a dry matter loss of 10\%; 2) the "plastic tarp" option with bales stored in a pyramid arrangement and covered with an appropriate plastic tarp; and a dry matter loss of 5\%; 3) the "roofed" option where bales are stored in a pyramid four rows high in a pole barn type structure with a roof and two or three sides enclosed, with a dry matter loss of $3 \%$. The tarp option was selected for the system analysis and a loss of 5\% was used for material stored at the regional storage site. Field and harvest losses are already accounted in the yield values. Maintaining alfalfa quality throughout storage is important to providing a quality coproduct, and reducing dry matter loss of both the leaf and_stem fractions. Alfalfa storage at remote locations would be selected to allow sites to be readily accessed throughout the year. Loading and unloading equipment, weigh scales, and alfalfa testing equipment will be located at the regional facilities when needed.

The biomass power plant is designed to operate about 310 days per year. Often power plant annual maintenance is scheduled during either the spring or fall periods of lighter power loads. It would require a minimum of material to be stored at the regional sites if annual maintenance of the power plant was schedule during the spring just prior to the beginning of hay harvest. The plant should be ready for full and continuous operation beginning June 1 . The power plant would then be constantly consuming alfalfa stems during the entire harvest season and beyond with minimal storage costs or post-harvest losses on direct-haul biomass. This report anticipates that $40 \%$ of total production will be direct-haul (no storage) and the remaining $60 \%$ stored at regional sites. The power plant is designed to operate about eleven months per year, with one month allowed for scheduled maintenance. Therefore, a significant portion of the total crop (60\%) must be stored for a period of time.

Approximately 680,000 tons of alfalfa must be transported from 50 to 80 remote storage sites to the processing plant annually (approximately. $2200 \mathrm{t} / \mathrm{d}$ )..Bales move from the regional storage sites to the processing plant on specially designed flat-bed trucks.A fleet of twenty trucks, working two shifts per day, 6 days per week for about 310 days per year delivers alfalfa to the plant. This would require a seasonal work force. Sites would be staffed with qualified persons to provide timely weighing, testing, unloading, and stacking of the alfalfa bales.A four day stockpile, of alfalfa stems is held at the plant for times when delivery is interupted by bad weather or other supply system problems. The electric power production can also be provided with natural gas, which is available on site. 
The alfalfa processing plant will borrow heavily on technology that has been developed over the last 40 years for the alfalfa dehydration industry.

The alfalfa arrives at the plant via truck in round bale form. The bales are put through a bale splitting operation to break up the bale and reduce the product size for processing.. Material loss and dust emissions are prevented by pulling air into the splitting operation and using the air to convey the alfalfa to the dryer. (See Figure. 1-3)

Drying serves two purposes: bulk moisture removal and flow smoothing. The gasifier requires a feedstock moisture level of $10-20 \%$ to maintain efficient gas production for the power plant. This gasifier operates best when feedstock moisture content varies slowly. This prevents the gasifier from receiving a "slug" of wet material. The dryer serves as a flow smoother since slugs of wet hay are intermingled with dryer hay so the average meets gasifier specifications.

Further separation of leaf and stem is accomplished as the alfalfa is dried in a rotary kiln type dryer. The tumbling action of the rotary dryer not only reduces the moisture, but continues the separation process by shaking leaves loose from the stems. On average, hay bales will arrive at the power plant with $15 \%$ moisture content. Since leaves have more surface area per pound than stems, they will dry more rapidly and to a lower value than stems. The leaf moisture will be reduced to about $2 \%$ while the stem material will be reduced to $10 \%$.

The heart of the separation system is the fractionating hammermill. It has been specifically designed for the separation of alfalfa. An air stream carries the alfalfa to the hammermill where it enters at one end of the casing. The stem fiber and the leaf are reduced in size by impact with hammers. A stationary screen surrounding $270^{\circ}$ of the rotor serves as a path through which the finer leaf particles may pass. A portion of the airflow is withdrawn through the screen and the leaf material with it. The stems tend to be too large and too tough to pass through the screen. The stem material that lays against the screen is subjected to a scrubbing action to remove the high protein outer layer. The remaining airflow causes the stems to migrate axially toward the outlet end of the hammermill casing and exit, for transport to the stem storage for the gasifier. The fractionating hammermill allows some control over the degree of separation by varying the leaf/stem airflow ratios. By pulling less air off the screen section, a lower fraction of leaf will be collected but at a higher purity level. Leaf material that was missed in the hammermill can be recaptured downstream because the process incorporates a rotary screen to further refine the separation operation. 
The leaf material is transported pneumatically to a negative pressure collector where the leaf and air are separated, and thèn on to a meal bin that meters the flow to the roasting operation. The roasting operation increases the bypass protein content for livestock. The output of the roasting operation will go to a pelletizing machine of standard design. A pellet cooler is required after the pelletizing machine because of the heat generated in the pellet machine. From the pellet cooler, the pellets will be conveyed by flight conveyor to a storage bin that has load-out capabilities for trucks.

\subsection{Alternative Feedstock Resources}

Alternative biomass feedstock resources are expected to contribute to the total fuel supply. The integration of other biomass resources supplementary to the base fuel supply provided by alfalfa would be a best use of existing biomass resources. Switchgrass, hybrid poplar, crop residues, and other crop rotation compatible biomass energy crops have potential to contribute to the fuel supply system. The maintenance of diversity within the biomass energy supply system is important not only from the standpoint of supply reliability but also to maximize profitability and promote the most judicious use of resources.

\section{Alfalfa feedstock produced in excess of current demand may be stored for several years under} proper conditions. Supply management will match production level with anticipated demand on an on-going basis. Although traditional markets for alfalfa are large and well established (Volume 1(8)), it is not anticipated that they will be used. The goal of this concept is to produce new products from alfalfa that would not impact existing alfalfa markets.

\subsection{Current Alfalfa Breeding Goals}

Alfalfa is grown in many areas of the world. It is a highly adaptable plant with aspects of genetic diversity that are exploited in various climates. Although alfalfa found its way to North AmericaIn earlier, in 1857, seed from Baden, Germany was introduced in Carver County, Minnesota by Wendelian Grimm. After many years of selecting seed from plants surviving Minnesota winters the variety "Grimm" was produced. Grimm proved winterhardy for north central states and Canada. The most rapid expansion of alfalfa acreage in this part of the country took place in the 1950's when varieties combining winterhardiness and resistance to bacterial wilt were developed.

Alfalfa grows under many diverse environmental conditions. It is noted for its tolerance of extremes in temperatures as well as its ability to survive moisture deficits. Adapted varieties have survived temperatures below $-35^{\circ} \mathrm{C}\left(-31^{\circ} \mathrm{F}\right)$ and above $50^{\circ} \mathrm{C}\left(120^{\circ} \mathrm{F}\right)$. Alfalfa becomes dormant during periods of drought and resumes growth when moisture conditions become favorable. In 
Minnesota, adapted disease resistant varieties usually maintain productive stands for four years following the seeding year.

Over sixty years of intense breeding activity by public institutions and private companies has resulted in persistent varieties with high yields, disease resistance, and winterhardiness. A program to select for tall, large diameter, and solid stems for use as biomass energy crop stock has been under way for several years in the USDA-ARS alfalfa breeding program at St. Paul, MN. A population of plants with the desired stem traits was selected in 1993, intercrossed in the greenhouse during the 1993-94 winter, and that seed sent to Prosser, WA, in April 1994 for a seed increase. This seed will be available for planting in May 1995, and should provide a basis for comparing current varieties with prototype populations under several biomass harvest systems. Plantings of various selected populations also were planted in 1994 in order that further selections could be made in 1995 .

The alfalfa management and production data previously obtained on varieties provides a realistic set of baseline data for judging the feasibility of the proposed biomass energy system. However, it should be possible to increase the efficiency (a combination of leaf and total yield) of the system by at least $25 \%$ if varieties similar to the proposed prototype variey were available. This could be accomplished within a period of about 6 years or the year 2000 . 


\section{TASK 4. THE CONVERSION TECHNOLOGY}

\subsection{The IGCC Process}

Electricity is produced from the alfalfa stems in an IGCC power plant. In a combined-cycle power plant electricity is produced by two separately powered turbine/generators. In the first cycle the turbine is powered by the combustion of biomass gas. The fuel for the combustion turbine is provided by the gasification of the alfalfa stems. The heat in the exhaust gas from the combustion turbine is reclaimed as steam in a heat recovery-steam generator (HRSG). This steam is used to power the turbine in the second cycle. By combining the cycles in this manner and integrating the combined cycles with the gasification process, the overall efficiency of the power plant is maximized. The gasifier is sized to process 1096 tons per day of alfalfa stems to meet the design load requirements of the combustion turbine. The gasification and power production operations are closely integrated as is shown by the ALFAGAS process diagram in Figure 1-4.

In the gasifier, the alfalfa stems are rapidly heated to gasification temperatures approaching $1650^{\circ} \mathrm{F}$ while in contact with air, bed material and steam at a pressure of $300 \mathrm{psig}$. Leaving the gasifier. the gases are cooled to $1020^{\circ} \mathrm{F}$ and cleaned so that the fuel gas entering the gas turbine meets the manufacturer's requirements.

The combustion turbine is one of Westinghouse's standard industrial designs, which has been modified to accommodate low-Btu biogas fuel. The turbine is equipped with Westinghouse's statc-of-the-art gas combustion system, which represents the Best Achievable Control Technology (BACT) for the mitigation of $\mathrm{NO}_{x}$ in combustion turbines. An output of $50.1 \mathrm{MW}$ of clectncal power is produced in the gas turbine generator.

The usable heat remaining in hot combustion gases leaving the gas turbine is recovered in the heat recovery steam generator (HRSG) in the form of superheated, high-pressure steam. The steam \ uxed to produce an additional $29.3 \mathrm{MW}$ in the steam turbine generator. The stack gases leas ing the HRSG meet or exceed all air quality requirements.

From the total 79.4 MW produced in the IGCC plant, $4.3 \mathrm{MW}$ is used internally as auxiliary equipment power, thus producing net power of $75.1 \mathrm{MW}$. The overall performance for the ALFAGAS IGCC plant is summarized in Table 4-1. The plant costs and economic analysis are presented in the Economics and Business Plan, Volume 3. 


\begin{tabular}{|c|c|c|}
\hline Parameter & Biomass Gas & Natural Gas \\
\hline Dried Biomass Feed Rate, lb/h (9.4\% moisture) & 91,300 & 0 \\
\hline Gasifier Heat Input (HHV), MMBtu/h & 669 & 0 \\
\hline Combustion Turbine Firing Rate (HHV), MMBtu/h(note a) & 614 & 574 \\
\hline Heat Export to Leaf Processing Plant & & \\
\hline - Steam @ 4,100 lb/h, MMBtu/h & 5 & 5 \\
\hline - Flue gas @ $310,000 \mathrm{lb} / \mathrm{h}, \mathrm{MMBtu} / \mathrm{h}$ & 20 & 20 \\
\hline Combustion Turbine Gross Power, kW & 50,100 & 53,300 \\
\hline Steam Turbine Gross Power, kW & 29,300 & 19,800 \\
\hline Gross Plant Output, kW & 79,400 & 73,100 \\
\hline Auxiliary Power, kW & 4,310 & 2,710 \\
\hline Net Plant Output, kW & 75,090 & 70,390 \\
\hline Net Plant Heat Rate (HHV), Btu/kWh & 8,910 & 8,155 \\
\hline Net Plant Efficiency (HHV), \% & 38.3 & 41.9 \\
\hline
\end{tabular}

(a) Biomass gas inlet temperature 1,020 F, HHV = 155 Btu/SCF, LHV = 143 Btu/SCF

\subsection{Suitability Of Alfalfa Stems For Gasification}

The alfalfa stem feedstock was analyzed chemically and physically. The analyses were compared with a similar biomass feedstock, namely bagasse, that has been successfully gasified in a fluidized-bed gasifier. The initial results are positive, and the alfalfa stems are expected to be as good as the bagasse feedstock for fluidized-bed gasification.

The alfalfa samples tested exhibited some variation in the amount and type of ash components between the stem and leaf fractions and also between the different growing regions around the proposed plant site. It is expected that these differences in ash constituents will not impact the proposed alfalfa gasification scheme, and this also needs to be evaluated with a large-scale gasification test.

\subsection{Investigation of Alfalfa Feedstock Properties}

Knowledge of the chemical and physical properties of the alfalfa feedstock are important to determine successful gasification operating conditions and feed handling operations. The important chemical properties of alfalfa include its moisture level, ultimate analysis, calorific value, and the elemental composition of the ash. Another chemical property important for gasification is char reactivity with steam. Reactivity of the biomass char carbon with steam is a measure of the slowest reaction step in the complete conversion of biomass into gases. After the very rapid devolatilization step, about $5 \%$ to $15 \%$ of the initial biomass weight remains as char 
carbon. The char carbon reacts with steam in the gasifier to complete the gasification process forming additional carbon monoxide and hydrogen. The rate of this reaction determines the char residence time in the fluidized bed, hence, is related to the size of the gasifier.

Also included with the physical properties is an assessment of the tendency of the ash constituents to combine and form agglomerates within the gasifier or in downstream equipment. Alkali elements such as potassium and sodium can combine with silica to form agglomerates in the gasifier. The boat tests conducted with the alfalfa stems showed a very weakly agglomerated mass of char and ash, but the addition of a magnesium based additive was found to prevent agglomeration. The design conditions for the gasification include the use of dolomite (a magnesium carbonate containing compound) as bed material to eliminate agglomeration.

\subsection{Gasification Process Conditions}

Based on data from the thermobalance test of the alfalfa char gasification rate at pressure and $1600^{\circ} \mathrm{F}$, and from the previous gasification test experience in the IGT RENUGAS PDU with the Hawaiian bagasse feedstock at $1580^{\circ} \mathrm{F}$, which yielded $96 \%$ feed carbon conversion, it is expected that an alfalfa gasification temperature near $1600^{\circ} \mathrm{F}$ should yield similar or greater feed carbon conversions.

The specification of the gasification system pressure is dictated by the requirements of the gas turbine power generation system and the sum of the pressure drops through the downstream equipment and piping. Based on these requirements the operating pressure of the air-blown alfalfa fluidized-bed gasifier was specified at $300 \mathrm{psig}$. The effect of pressure on the inherent gasification reactions or conversion efficiency is small, thus pressure is not a gasification process design variable. Generally, higher operating pressures allow greater biomass throughput for a given cross-sectional area of the fluidized bed, thus allowing for smaller diameter vessel design. Also, the quality of fluidization in the gasifier is enhanced as higher pressure creates smaller bubbles, which contribute to better mixing. Higher operating pressures, however, require more inert gas for the lockhopper operation of the alfalfa feeding system.

\subsubsection{Technical Challenges: Pilot Plant Testing}

One alfalfa gasification test was conducted at the IGT RENUGAS Pilot Plant during a concurrent DOE program which was examining hotgas cleanup components. The entire alfalfa plant was gasified. Results showed that the alfalfa carbon conversion was about $98 \%$ and the product gas composition was similar to bagasse as had been assumed. In this limited test, the conditions were not optimized for the alfalfa as have been done for this study, but overall the test 
indicates alfalfa can be successfully gasified. The alfalfa feedstock appears to be suitable as a gasification feedstock, however, further testing is needed. Gasification tests of the alfalfa feedstock at a larger scale will provide information on the gasification process parameters and will produce useful design information for the handling and feeding systems.

\subsection{Gasification and Power Island Design}

\subsubsection{Combustion Turbine Selection}

The Westinghouse 251B12 combustion turbine, as shown in Figure 4-1, was selected for the Alfagas plant based on several criteria. The input fuel requirement for the turbine matches the output of a single pressurized gasifier with a capacity of 1096 tons per day of alfalfa stems. The turbine combustor is adaptable for low-Btu fuel gas combustion. Satisfying the above criteria plus the fact that the 251B series combustion turbine is a tried and proven engine with over 200 units installed and never having missed a performance guarantee, it was determined that there was little risk in using it as the basis for the plant design.

\subsubsection{Adaptability of Combustion Turbine to Low-Btu Fuel Combustion}

Westinghouse combustion turbines utilizing low heating value fuels date back to the 1950 s with the conversion of the W201. Several models of Westinghouse combustion turbines have been modified to combust fuel with a heating value as low as $80 \mathrm{Btu} / \mathrm{SCF}$. Two MW251 combustion turbines built by Mitsubishi Heavy Industries (a Westinghouse technical alliance partner) based on the Westinghouse 251B combustion turbine design were modified in 1989 to combust lowBtu gas from steel mill blast furnaces. DOW Chemical successfully operated a modified Westinghouse W191 combustion turbine on $80 \mathrm{Btu} / \mathrm{SCF}$ coal gas in the early $1980 \mathrm{~s}$ and has successfully operated two modified Westinghouse 501D combustion turbines on $239 \mathrm{Btu} / \mathrm{SCF}$ coal gas for the past 6 years at their Plaquemine, Louisiana chemical plant. The combustion system designed for use with the modified 501D engines is being evaluated for use on the 251B12 for this project.

An additional alternative is the multi-annular swirl burner (MASB) combustor being developed by Westinghouse under a Department of Energy Clean Coal program. This particular combustor is being designed specifically for use with high-temperature, low-Btu synfuels that contain large amounts of fuel-bound nitrogen (FBN). These larger MASB combustors have been conceptually designed for 251B12 IGCC application. 


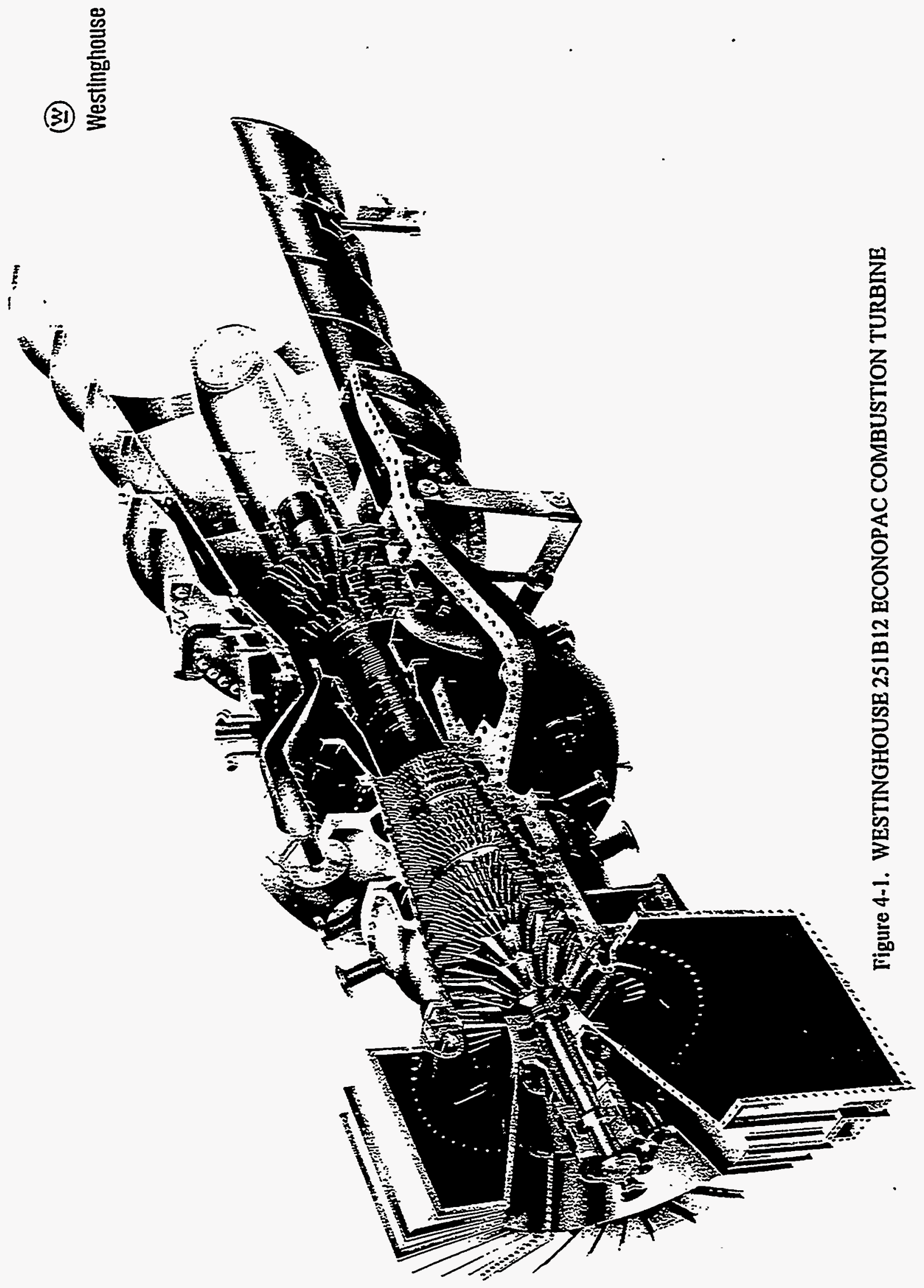




\subsubsection{Gasifier Capacity}

The gasifier system capacity is determined by the heat consumption of the gas turbine. The gasifier island is sized to provide sufficient quantities of low-Btu biomass gas to the gas turbine/generator in order for it to generate the design electrical power output. Biomass feed rate and reagent consumption rates are determined by gasifier reaction kinetics and thermodynamic considerations. Based on the Westinghouse 251B12 gas turbine, it was determined that the gasifier will use 1096 tons per day of dried alfalfa stems at $9.4 \%$ moisture.

\subsubsection{Gasification Plant Design}

The gasification plant includes the following system components: biomass receiving and feeding, gasification, and hot gas cleanup. The gasification reactions occur among the biomass, air, and steam in a hot bed of inert, partially calcined dolomite (or limestone). Dried alfalfa stems with the proper size consist is conveyed from the leaf processing plant to storage silos adjacent to the gasifier building. From the silos the fuel is delivered to a weigh hopper, located in the gasifier building. From there it is transferred to a lockhopper/screw feeder system and is fed into the fluidized-bed gasifier. A dolomite feed system is also provided to maintain the inventory of inert material in the fluidized bed. The feeding system uses inert gas for pressurization.

In the gasifier, the carbon and the volatile matter in the biomass react with air and steam at a temperature typically between $1550^{\circ} \mathrm{F}$ and $1750^{\circ} \mathrm{F}$. Bed temperatures depend on fuel moisture and the bed/freeboard air ratio. Freeboard temperature is controlled by secondary air injection. Typical operating pressure is $300 \mathrm{psig}$. The product gas contains carbon monoxide, carbon dioxide, methane, hydrogen, water vapor, and nitrogen. In addition, small amounts of vaporized light tars, ammonia, hydrogen sulfide, and other trace impurities are also present.

The fluidizing and gasifying media are mixtures of air and steam. Gasification air is extracted from the compressor of the gas turbine and fed into the gasifier through a booster compressor. Steam is extracted from the steam turbine. The fluidizing mixture is fed into the reactor through a distributor plate (a sloping grid at the bottom of the bed) to maintain fluidization. The gasification air is.introduced through a central jet pipe into the middle of the fluidized bed thus maintaining intensive internal circulation and mixing of the gasifier bed, which results in high gasification rates. 
The fluidization regime in the gasifier is in between conventional bubbling bed and circulating fluidized-bed conditions: the gasifier operates as a so-called spouting bed with intensive circulation of solids from top to bottom. This feature guarantees rapid gasification reactions and long residence times of solids, thus promoting the cracking of tars to more desirable hydrocarbon compounds. Freeboard temperature is maintained by air injection which further mitigates the formation of tars and ammonia.

The gasifier incorporates a cyclone system to recycle the carry-over fines. The fines circulating through the cyclone consist of bed material, ash, and biomass char, which are retumed to the lower part of the fluidized bed where the residual carbon reacts rapidly with the fresh oxidant.

The inert material, which inevitably accompanies the fuel (stones, sand, etc.) and the larger particles of the bed material itself, will sink to the bottom of the fluidized bed. These are removed through the bottom discharge system, which contains a water-cooled screw and a depressurizing lockhopper system.

Biomass gases exiting the cyclone system are cooled in the product gas cooler to $1020^{\circ} \mathrm{F}$, the maximum temperature tolerated by the gas turbine control valve. The product gas cooler is a fire-tube type boiler, which generates saturated steam. This cooler is tied-in with the steam cycle plant and the steam being generated and directed to the HRSG steam drum.

Hot gas cleanup (HGCU) is a key component of the simplified IGCC process. The advantages of hot gas cleanup over conventional scrubbers include a higher overall efficiency due to utilization of the sensible heat of the gas, the elimination of process liquids and their treatment for disposal, a less complex system to operate, and a lower investment cost. The product gas is cleaned to protect the gas turbine and to comply with environmental regulations. The main contaminants in biomass gas are tars, particulate, ammonia, and alkali metals. Very low concentrations of hydrogen sulfide may also be present from the sulfur in the feed. Biomass typically has less than 0.1 weight percent sulfur, therefore, $\mathrm{SO}_{\mathrm{x}}$ emissions are usually not an environmental issue. The formation of tars is kept to an inconsequential minimum by the use of Tampella's gasification technology.

Biomass usually contains alkali metals that can form compounds, which may cause fouling and lead to high-temperature corrosion in the gas turbine. The alkali metals exit the gasifier as finely dispersed solids, liquids, and gases. As the gas stream is cooled, these materials condense, coalesce, and become attached to the particulate matter, which subsequently is captured by the 
hot gas filter. These contaminants include sodium and potassium chlorides and hydroxides. The concentration of the vapor phase alkalis leaving the filter is typically below $0.05 \mathrm{ppm}$, which is acceptable to the 251B12 combustion turbine.

The particulate separated from the product gas by the HGCU filter elements is periodically cleaned from the filter elements with pulses of nitrogen gas. The particulate collects in the bottom cone ash hopper of the HGCU vessel where it is then removed through a bottom discharge system consisting of a water-cooled screw and a pressure letdown system similar to the gasifier vessel.

Fuel-bound nitrogen (FBN), primarily ammonia, in synfuels is of concern because the ammonia tends to selectively convert to $\mathrm{NO}_{x}$ during combustion. Minimizing this conversion of ammonia to $\mathrm{NO}_{x}$ will be an important design consideration in the selection of the $251 \mathrm{~B} 12$ combustion system for this project.

\subsubsection{Power Plant}

The power plant includes the following system components: combustion turbine-generator, heat recovery steam generator, steam turbine-generator, and balance-of-plant equipment. Ambient air is drawn through the inlet air filtration and silencing system into the compressor element of the combustion turbine where it is compressed to approximately 14 atmospheres. The combustion turbine will be designed to fire low-Btu biogas and natural gas. Fuel is fired in the combustion section. after which the hot gases expand through the turbine element. The combustion turbine is connected to its air-cooled generator through a speed reduction gear. The combustion turbine has two functions: 1) to produce electrical power, and 2) to supply hot gases to the heat recovery steam generator (HRSG). Exhaust from the combustion turbine passes through the HRSG using its heat to generate steam. The gas is discharged into the atmosphere through the stack. Plant gascous emissions are controlled with the use of a biogas combustion system.

The HRSG forms the link between the combustion turbine and the steam turbine. It is a horizontal gas flow type heat recovery boiler, which incorporates extended fin tube construction. Thu particular combined-cycle plant utilizes a three pressure non-reheat HRSG design. The high-pressure (HP), intermediate-pressure (IP), and low-pressure (LP) sections contain an economizer tube bundle, a natural circulation type evaporator tube bundle with a steam drum, and a superheater tube bundle. High-pressure and intermediate-pressure feedwater is pumped through the economizer sections of the HRSG. 
The steam generated in the HRSG is supplied to the non-reheat single-cylinder, axial flow condensing steam turbine. Intermediate-pressure induction steam is mixed with the main steam flow at the appropriate pressure level in the turbine blade path. The steam turbine has an intermediate extraction to provide steam for gasifier operation. When the combustion turbine is operated on natural gas, steam injection is required for $\mathrm{NO}_{x}$ control. It is taken from the HRSG high-pressure steam header upstream of the throttle valve. Steam exhausts into a water-cooled condenser located at the end of the steam turbine. The condensed steam (condensate) is pumped through the feedwater heater to the deaerator integral with the HRSG. Intermediate highpressure steam, as well as hot flue gas, are also taken from the HRSG and exported to the adjacent leaf processing plant for process use and leaf drying, respectively.

The steam turbine is directly connected by a rigid coupling to a direct air-cooled generator that produces electrical power. Steam is condensed in a wet surface condenser. The condenser is a side entry design to accommodate the axial exhaust from the steam turbine. The condenser is designed to allow $100 \%$ steam bypass of the steam turbine. Condensate is removed from the condenser hotwell by two of three $50 \%$ capacity condensate pumps. Pumped condensate passes through the feed water heater section of the HRSG prior to entering the deaerator. The steam cycle ultimate heat sink is provided by a mechanical draft cooling tower.

The combustion turbine generator and steam turbine generator are connected to a two-winding, oil-filled step up transformer, which increases the voltage at the generator terminals to the interconnecting voltage at the high side terminals. Included are the provisions for the automatic synchronization and protection of the combustion turbine-generator.

\subsubsection{Integration with the Fuel Preparation and Alfalfa Processing Plant}

The integration of the IGCC plant with the alfalfa processing plant allows a portion of heat requirement for the drying and conditioning of the alfalfa, that is received at the processing plant, to come from low grade heat sources from the HRSG. The heat requirement for the alfalfa leaf processing is taken from an extraction point on the steam turbine.

\subsubsection{Fluidized-Bed Gasifier}

Biomass gasification takes place in a refractory-lined carbon steel vessel. The gasifier is a vertical pressure vessel designed in accordance with ASME requirements. The gasifier vessel measures 15 feet OD and has an overall height of 80 feet.

The gasifier vessel has tapered transitions between the freeboard and the fluidized bed. Start-up burners are an integral part of the gasifier design. The lining consists of high-temperature 
firebrick and castable refractory, backed by insulating refractory. Sufficient insulating refractory is provided to keep the gasifier metal shell temperature at about $200^{\circ} \mathrm{F}$, well below the $570^{\circ} \mathrm{F}$ design limit. The internals of the gasifier include proprietary designs for the fluidizing gas distribution and fly ash recycle systems.

The combustion turbine drives from the cold compressor-end, with the turbine solidly coupled to the generator through the horizontally offset main reduction gear. The air-cooled generator and brushless exciter are equipped with integral lubricating oil and cooler piping, and necessary instrumentation.

\subsubsection{Low-Btu Fuel Combustion System}

The product gas from air-blown alfalfa gasification differs from traditional combustion turbine fuels in three ways: first, it has a lower heating value (approximately $15 \%$ of the value of natural gas); second, the gasifier product gas will enter the combustion turbine at $1020^{\circ} \mathrm{F}$; and third, it contains significant quantities of FBN.

\subsubsection{Steam Turbine System}

The steam turbine proposed for the Alfagas IGCC project is based on the Westinghouse SingleCase family of combined HP-LP steam turbines as shown in Figure 4-2

\subsubsection{Heat Recovery Steam Generator}

The heat recovery steam generator is the link between the combustion turbine and steam turbine. It's performance is dependent on the combustion turbine exhaust flow rate, temperature, and composition. The HRSG is a horizontal gas flow.type heat recovery boiler which incorporates extended fin tube construction. This particular combined-cycle plant utilizes a three pressure level unit with an integral feedwater heater and deaerator. The HRSG provides feedwater to the gasifier gas cooler which in turn provides high-pressure saturated steam back to the HRSG. This steam is superheated and sent to the steam turbine to generate power. In addition, the HRSG also provides the steam for $\mathrm{NO}_{\mathrm{x}}$ control in the combustion turbine when it is operated on natural gas.

Intermediate high-pressure steam, as well as hot flue gas, are also taken from the HRSG and exported to the adjacent leaf processing plant for process use and leaf drying, respectively. 



\subsection{Plant Operation and Maintenance}

\subsubsection{Operation}

Operating a gasifier is similar, in principle, to operating a fluidized-bed boiler. The air-to-fuel and steam-to-fuel ratios are controlled to maintain optimum gasification conditions. The fuel feed is set by the gas turbine fuel demand (basically, a fuel gas pressure control). The turndown capability is about $50 \%$, the limits being set by the fluidized bed. Cold start-up time is approximately 24 hours, during which the gasifier and downstream vessels like the HGCU are heated up by gas burners with the off gases directed to the flare. After the inert bed material has been fed to the gasifier and heated, the biomass fuel feed is started. Normal shutdown takes approximately 8 hours. In an emergency situation, the gasifier is first cooled with inert gas, then with steam.

For a 75-MW biomass IGCC plant (gasification and power plants) the total staff consists of between 30 and 35 persons, including management, supervisors, operators, permanent maintenance staff, laboratory staff, and materials handling persons. The actual number depends on the site-specific arrangements for fuel preparation, ash handling, and whether the IGCC plant can share some functions with the existing plant. The skill level required from the gasifier operators is comparable to the skills of people operating solid fuel-fired boilers and chemical recovery boilers. The initial training for key plant operators will be at Tampella's pilot plant. A computer simulator will be used for onsite operator training. An essential part of the training will be done by having the operators participate in the construction check-out and commissioning of the plant.

\subsection{IGCC Plant Performance}

\subsubsection{Design Criteria}

The IGCC plant performance is based on site ambient conditions of $59^{\circ} \mathrm{F}$ and $60 \%$ relative humidity. The proposed plant site elevation is 950 feet above sea level.

\subsubsection{Overall Plant Performance Summary}

The IGCC plant will be operated as a base-loaded plant. Start-up power will be provided from an adjacent existing station. During the first year of operation, the gasification plant is expected to have an availability of less than $50 \%$. The gasification plant availability will increase from the $82 \%$ to $88 \%$ range after the first 3 years of operation. 
Full-load plant performance parameters are presented in Table 4-1 (see page 40). The plant net output is $75.1 \mathrm{MW}$, with a net plant heat rate of $8910 \mathrm{Btu} / \mathrm{kWh}$ at full load. The full-load auxiliary power requirements are $4.3 \mathrm{MW}$. The overall plant performance on natural gas backup fuel is also given in Table 4-1 for comparison purposes.

\subsubsection{Combustion Turbine Performance}

Full-load combustion turbine performance data at $59^{\circ} \mathrm{F}$ is shown in Table 4-2. The performance is based on burning low-Btu biomass gas from the gasifier and on extracting $123,900 \mathrm{lb} / \mathrm{h}$ of compressor air mass flow to supply the gasifier compressed air requirements. Combustion turbine power output is approximately $50 \mathrm{MW}$, and the biomass gas heat input is $614 \mathrm{MMBtu} / \mathrm{h}$ (HHV), which includes the sensible heat of the hot fuel gas. The combustion turbine performance on natural gas with steam injection for $\mathrm{NO}_{\mathrm{x}}$ control is also given in Table 42 for comparison purposes.

\begin{tabular}{|c|c|c|}
\hline Parameter & Biomass Gas & Natural Gas \\
\hline $\begin{array}{l}\text { Fuel Consumption (HHV), MMBtu/h (note a) } \\
\text { Combustion Turbine Gross Power, } \mathrm{kW} \\
\text { Steam Injection, lb/h } \\
\text { Aur Extraction, } \mathrm{lb} / \mathrm{h} \\
\text { Exhaust Flow, lb/h } \\
\text { Exhaust Temperature, of } \\
\text { Exhaust Composition, \% vol. } \\
\text { Oxygen } \\
\text { Water Vapor } \\
\text { Carbon Dioxide } \\
\text { Nitrogen and Argon } \\
\text { Estımated Emissions (at Gas Turbine Exhaust) } \\
\mathrm{NO}_{\mathrm{X}} \text { (as } \mathrm{NO}_{2} \text { at } 15 \% \mathrm{O}_{2} \text { ), ppmvd } \\
\mathrm{CO} \text { ppmvd } \\
\mathrm{SO}_{\times}\left(\text {as } \mathrm{SO}_{2} \text { ), ppmuw }\right.\end{array}$ & $\begin{array}{l}614 \\
50,100 \\
\text { None } \\
123,900 \\
1,397,500 \\
973 \\
12.8 \\
7.5 \\
6.2 \\
73.5 \\
40 \\
25 \\
40\end{array}$ & $\begin{array}{l}562 \\
53,300 \\
64,400 \\
\text { None } \\
1,383,900 \\
970 \\
12.9 \\
13.8 \\
2.9 \\
70.4 \\
25 \\
22 \\
0\end{array}$ \\
\hline
\end{tabular}

(a) Bromass gas temperature 1,020 $\mathrm{F}, \mathrm{HHV}=155 \mathrm{Btu} / \mathrm{SCF}, \mathrm{LHV}=143 \mathrm{Btu} / \mathrm{SCF}$

\subsubsection{Steam Turbine Performance}

The heat recovery steam generator (HRSG) is a three-pressure level unit with an integral deaerator. The HRSG provides feedwater to the gasifier gas cooler and steam to the steam turbine to generate power. It also receives high-pressure saturated steam from the gas cooler. This steam is superheated and sent to the steam turbine. The HRSG's performance is dependent 
on the combustion turbine exhaust flow rate, temperature, and composition. The steam turbine is of the condensing type. It exhausts to a conventional steam surface condenser at 1.25 inches $\mathrm{Hg}_{\mathrm{A}}$. The major performance parameters at the design point are listed in Table 4-3 along with the performance for natural gas operation.

\begin{tabular}{|c|c|c|c|}
\hline Parameter & $\begin{array}{c}\text { Flow } \\
\mathrm{lb} / \mathrm{h}\end{array}$ & $\begin{array}{l}\text { Pressure, } \\
\text { psia }\end{array}$ & $\begin{array}{c}\text { Temperature } \\
{ }^{\circ} \mathrm{F}\end{array}$ \\
\hline $\begin{array}{l}\text { Biomass Gas Operation } \\
\text { Throttle } \\
\text { Extraction to Gasifier } \\
\text { LP Admission } \\
\text { Exhaust to Condenser }\end{array}$ & $\begin{array}{c}222,800 \\
10,057 \\
4,100 \\
221,700\end{array}$ & $\begin{array}{c}1,014 \\
396 \\
192 \\
1.25^{\mathrm{a}} \mathrm{Hg}_{\mathrm{A}}\end{array}$ & $\begin{array}{c}900 \\
697 \\
449 \\
86\end{array}$ \\
\hline $\begin{array}{l}\text { Natural Gas Operation } \\
\text { Throttle } \\
\text { Extraction to Combustion Turbine } \\
\text { LP Admission } \\
\text { Exhaust to Condenser }\end{array}$ & $\begin{array}{c}115,155 \\
53,067 \\
27,397 \\
153,186 \\
\end{array}$ & $\begin{array}{r}594.1 \\
582.9 \\
129.9 \\
1.25^{\mathrm{H}} \mathrm{Hg}_{\mathrm{A}} \\
\end{array}$ & $\begin{array}{c}931.6 \\
931.6 \\
421.1 \\
86 \\
\end{array}$ \\
\hline
\end{tabular}

(a) Desuperheated with $11,609 \mathrm{lb} / \mathrm{h}$ of feedwater @ $86^{\circ} \mathrm{F}$ to provide $64,676 \mathrm{lb} / \mathrm{h} @ 415 \mathrm{psia} / 550^{\circ} \mathrm{F}$.

\subsubsection{Emissions Summary}

Total IGCC gaseous, solids, and aqueous plant emission rates at full load are shown in Table 4-4. The expected sulfur oxide ( $\mathrm{SO}_{\mathrm{x}}$ as $\mathrm{SO}_{2}$ ) emission rate is $127 \mathrm{lb} / \mathrm{h}$. Sulfur reduction is not provided for by the gasification plant. The biomass feedstock sulfur content is low, less than 0.1 weight percent sulfur, and $\mathrm{SO}_{\mathrm{x}}$ emissions are not an environmental concern. Some sulfur capture will take place by the gasifier bed, but this is not reflected by the $\mathrm{SO}_{\mathrm{x}}$ emissions figure.

The expected nitrogen oxide $\left(\mathrm{NO}_{\mathrm{x}}\right.$ as $\mathrm{NO}_{2}$ ) emission rate is $99 \mathrm{lb} / \mathrm{h}$. $\mathrm{NO}_{\mathrm{x}}$ is controlled to 40 ppmvd (parts-per-million by volume on a dry gas basis) at $15 \% \mathrm{O}_{2}$ by a combination of fuelbound nitrogen-to-ammonia reduction by the gasifier system and by the use of special low-Btu fuel combustion turbine combustors. High-temperature, low-Btu fuel combustor development is presentiy being performed by Westinghouse and is expected to be available on a commercial basis during the time frame of this project. 


\begin{tabular}{|c|c|c|}
\hline Item & Biomass Gas & Natural Gas \\
\hline $\begin{array}{l}\text { Gaseous Emissions } \\
\mathrm{SO}_{\times}\left(\text {as } \mathrm{SO}_{2}\right) \\
\mathrm{NO}_{\times}\left(\text {as } \mathrm{NO}_{2}\right) \\
\mathrm{CO} \\
\mathrm{PM}(10) \\
\mathrm{UHC}\end{array}$ & $\begin{array}{l}127 \mathrm{lb} / \mathrm{h} \text { (40 ppmvw) } \\
99 \mathrm{lb} / \mathrm{h} \text { (40 ppmvd @ 15\% O2) } \\
32 \mathrm{lb} / \mathrm{h} \text { (25 ppmvd) } \\
6 \mathrm{lb} / \mathrm{h} \text { (4 ppm weight) } \\
15 \mathrm{lb} / \mathrm{h} \text { (20 ppmvd) }\end{array}$ & $\begin{array}{l}\quad 0 \\
62 \mathrm{lb} / \mathrm{h}\left(25 \mathrm{ppmvd} @ 15 \% \mathrm{O}_{2}\right) \\
28 \mathrm{lb} / \mathrm{h} \text { (22 pmvd) } \\
5 \mathrm{lb} / \mathrm{h} \text { (3.5 ppm weight) } \\
3 \mathrm{lb} / \mathrm{h} \text { (20 ppmvd) }\end{array}$ \\
\hline $\begin{array}{l}\text { Solids Emissions } \\
\text { Bottom ash, lb/h } \\
\text { Fly ash, lb/h }\end{array}$ & $\begin{array}{l}4,700 \\
1,800\end{array}$ & $\begin{array}{l}0 \\
0\end{array}$ \\
\hline $\begin{array}{l}\text { Aqueous Emissions } \\
\text { Boiler Blowdown, } \mathrm{lb} / \mathrm{h}\end{array}$ & 2,200 & $<2,200$ \\
\hline
\end{tabular}

ppmvw = parts-per-million by volume on wet gas basis ppmvd = parts-per-million by volume on dry gas basis ppm weight $=$ parts-per-million on weight basis

The bottom and fly ash product rates are $4700 \mathrm{lb} / \mathrm{h}$ and $1800 \mathrm{lb} / \mathrm{h}$, respectively. The ash will contain biomass feedstock ash, bed material, and very small quantities of unburned carbon. The ash is expected to be an inert material suitable for return to the land. The ash characteristics will be determined from samples collected from future pilot plant tests.

Aqueous emissions from the IGCC plant are $2200 \mathrm{lb} / \mathrm{h}$ and consist of boiler blow-down. 


\section{TASK 5. ENVIRONMENTAL MONITORING}

\subsection{Power Plant Monitoring}

The power plant emissions will be regulated by the EPA New Source Performance Standards (NSPS). NSPS sets limits for $\mathrm{NO}_{\mathrm{X}}, \mathrm{SO2}$, particulates, C), and VOC's and also sets requirements for monitoring. Under some conditions, the New Source Review section of NSPS requires monitoring each of these pollutants for 2 years prior to initial operation of the plant to establish a background level. NSPS sets the standards for the monitoring program such as location of the monitors and sampling techniques.

After the plant is in operation, continuous emissions monitoring (CEM) will be required for $\mathrm{S} 02$, $\mathrm{NO}_{\mathrm{x}}$, and particulates. NSPS regulations set forth the specifications for the CEM instruments, and the installation. NSPS calls out the requirements for maintenance and calibration of the instrument. NSPS covers emissions reporting requirements and notification of violations.

\subsection{State Of The Biomass Shed And Monitoring Plan}

The Minnesota River contributes more diffuse source pollution to the Mississippi River System than any other river in the state. Introduction of alfalfa into the predominate com-soybean rotation in Southwestern Minnesota will have a large impact on reducing the diffuse source pollution associated with erosion (total P, Biological Oxygen Demand, and sediment) entering the Minnesota River. This reduction may, however, be offset somewhat by soluble P lost from alfalfa fields during the snowmelt period. The University of Minnesota (Volume 1(10.2) proposes an environmental monitoring and research plan to quantify the impact of a significant change in cropping pattern on the watershed. 


\section{TASK 6. MARKET ISSUES}

\subsection{Electricity Sales And Market Price Structure}

\subsubsection{Economic Dispatch Rules}

NSP uses a computer controlled dispatch system to regulate which units are called upon (dispatched) and the load level at which they operate. This is a dynamic system that is constantly responding to the changing system load. The system is driven by economics - it is always looking for the lowest cost next increment of power. As such, the incremental cost of the alfalfa power plant must be low enough that the control system will "choose" it. The incremental cost includes primarily the cost of fuel but also adds some operating and maintenance costs that are strictly output related. The incremental cost does not include fixed costs such as plant staff or capital costs. Currently, the lowest cost providers are the nuclear and large coal burning plants. The cost of the alfalfa power plant must be on a par with these plants if it is to run enough hours to meet financial goals.

\subsubsection{Sulfur Dioxide Offset}

The proforma for this project does not include credits for a sulfur dioxide offset however these credits could be used to further enhance profitability.

Congress passed the Clean Air Act in 1990 to reduce emissions from power plants. The result, when fully implemented in 2003 , will be 10 million fewer tons/year of sulfur dioxide emitted to the atmosphere. As an incentive to reducing emissions in a cost effective manner and also to rew ard those who have already reduced $\mathrm{SO}_{2}$ emissions, it established a marketing mechanism for SO: allowances.

Tule IN of the 1990 Clean Air Act allows the trading of $\mathrm{SO}_{2}$ allowances. One allowance authonzes a utility to emit one ton of $\mathrm{SO}_{2}$. If allowances are trading at $\$ 150 /$ ton, a recent price, an amount equal to $\$ 71,000$ ( $\$ 150 /$ ton $\times 473$ tons/yr) would need to be purchased annually to bring the SO: effect of operating the plant to zero.

L'ulitues can carn tradable emissions allowances from the EPA's Conservation and Renewable Energ! Reserve which has 300,000 allowances to award. The allowances are earned by either adopung cfficiency measures or implementing renewable energy projects. It is not clear how a biomass project such as alfalfa would qualify for these allowances if it had an $\mathrm{SO}_{2}$ emission rate higher than a new coal fired plant as it currently does. The EPA began accepting applications for 
these allowances on July 1, 1993 and awards the allowances on a first-come, first-served basis. The application form is a simple two-sided form. Application for an efficiency credit takes more time for approval than renewable energy because DOE must first certify that the utilities ratemaking process does not make energy conservation unprofitable.

$\mathrm{SO}_{2}$ allowances can be gained in three ways by implementing a renewable energy program such as wind, solar, hydro, or biomass. The first method, Avoided Emissions, means that the energy produced from a renewable source replaces energy that would have been produced from a conventional source. It is assumed that the amount of tons of $\mathrm{SO}_{2}$ produced by renewable energy is less than the amount from the conventional source, therefore unused allowances are produced that can be sold or banked to be used later to comply with Phase II of the Acid Rain Program (part of the 1990 Clean Air Act). The value, if sold, is the market value of the allowances. Currently, the market value is in the $\$ 150 /$ ton range. The number of allowances produced depends on what units were displaced and their emission rates. Best case is if all the allowances were sold from one years production of $\mathrm{SO}_{2}$ from the biomass plant and would be:

$669 \mathrm{Mbtu} / \mathrm{hr}$ x 8760 hours/year x .85 Capacity Factor x .19 lb SO$/ 2 / \mathrm{Mbtu} / 2000 \mathrm{lb} / \mathrm{ton}=473$ tons/ year.

If multiplied by $\$ 150 /$ ton, the annual savings are $\$ 71,000$.

A second way to get allowances is from the Conservation and Renewable Energy Reserve, as previously described, from a pool of 300,000 allowances that have been set aside nationally. Application for allowances from this reserve must be made by the utility. Allowances are awarded at the rate of one allowance per $500 \mathrm{Mwh}$ of energy production annually. For the alfalfa biomass plant, this would be $75 \mathrm{Mw} \times 8760$ hour/year x .85 Capacity Factor $=558,450$ Mwh/year energy produced $/ 500 \mathrm{Mwh}=1117$ allowances. The value of the allowances at current rates is 1117 allowances $\mathrm{x} \$ 150$ / allowance $=\$ 167,500 /$ year.

A third way to get allowances is to Reduce Utilization of a unit thereby saving emission allowances that had been attributed to that unit. The value of using this method is very similar to Avoided Emissions. 


\subsubsection{Power Purchase Contract}

The energy output and capacity of the alfalfa project will be compensated by the electric utility at rates that are negotiated at project inception. The right to enter into a power purchase contract with the utility is won by successfully bidding to a Request For Proposal issued by the electric utility.

\subsection{Co-Product Sales And Market Price Structure}

\subsubsection{Product Value}

The alfalfa leaf meal value is established by comparison with other protein products with which it will compete. Volume 1 (7) includes a detailed discussion of how the alfalfa product will supplant other protein products in the livestock diet and the relative feed value of each.

\subsubsection{Alfalfa Leaf Meal Markets}

Alfalfa leaf meal will compete in the marketplace with soybean meal and other protein feedstuffs. Soybean meal is the market leader. Total U.S. soybean meal production in 1994 was just under 30 million tons (USDA). Total alfalfa leaf meal production from the proposed demonstration plant is anticipated at approximately 320,000 tons/year about $1 \%$ of U.S. soybean meal production. Soybean meal sold for an average price of $\$ 178 /$ ton in 1994. Alfalfa leaf meal (28\% crude protein) will enter the marketplace at a discount to soybean meal (44\% crude protein) based strictly on protein content. Alfalfa meal may however find higher value markets based on amino acid profile and other unique characteristics of the meal. Higher value markets will require demonstration of feed value via livestock feeding trials and test marketing prior to large scale acceptance and significant market penetration.

Bypass protein enhancement of alfalfa leaf meal is anticipated in the design parameters of the alfalfa processing plant. Bypass protein has a higher value as livestock feed for ruminant animals (Volume 1 (7)) than unprocessed meal. A major market for bypass protein is for high-producing dairy cattle. At a recommended ration formulation level of ten pounds of bypass protein per day per cow for a three month (high-lactation) period during a year, dairy cows in Minnesota would consume essentially the entire annual production of leaf meal from the proposed commercialscale demonstration plant.

Alfalfa leaf meal products and other alfalfa-derived products are likely to find significant market opportunities as discussed in Volume 1 (7.2). Further research and development of alternative markets will continue during the validation phase of this project. 


\subsection{Policy Issues:}

The 1995 Farm Bill will set agricultural policy that will in large part determine the level of participation of farmers in the production of energy crops on CRP and other lands. A major issue of concern is what effect planting energy crops will have on a farms crop-base acreage. Inceased flexibility for farmers and farm program incentivea for the production of energy crops would have a major positive impact on biomass energy production.

Most policy analysts believe these changes are likely, however, it must be emphasised that federal farm policy will play a very significant role in determining farmer adoption rate for energy crops production. Farmers would be unlikely to plant energy crops if by doing so they placed their farm at a competitive disadvantage relative to the farm program.

The Conservation Reserve Program (CRP) may be continued with the following important costsaving modifications. CRP acreage that should remain out of production for environmental reasons (about $25 \%$ of total enrollment) should be continued in the program under long-term CRP policy. Lands currently in CRP that are capable of producing food, fiber, and energy crops (about 50\% of enrollment) if managed within an environmentally sound biomass energy production system could receive a reduced CRP payment. This biomass energy production incentive would stimulate biomass energy crop production, limit the increase in commodity crop acreage on CRP lands returning to production, and provide positive environmental benefits. Finally, the most productive lands in the current CRP program (about $25 \%$ of enrollment) may be phased out of the program to a market-based system through a mechanism that provides a minimal incentive payment for energy crop production for a limited time.

\subsection{Crop Insurance}

Crop insurance available in part or all of the project area include hail insurance, federal multiple peril crop insurance and a pilot forage group risk plan. In addition to these existing insurance plans the biomass producers cooperative may wish to investigate a self- insurance, special group coverage, or other risk management options for its members (Volume 11(3). 


\section{TASK 7. SOCIO-ECONOMIC \& ENVIRONMENTAL IMPACT}

\subsection{Economic Impact}

\subsubsection{New Industries And Business Opportunities}

Diversification of the agricultural base will provide economic stimulus for small business development and provide greater economic stability in the region. Typically a farmer might handle alfalfa production from seedbed preparation to market. This need not be the case. Many aspects of alfalfa production on a large scale could involve the use of specialty equipment, custom operators, and consultants. The following is a partial list of some of the areas where private contractors could become involved: Seedbed Preparation and Alfalfa Seeding, Crop Consultants, Alfalfa Harvesting Operations, Alfalfa Transport from Field to Remote Site, Alfalfa Storage, Alfalfa Testing, and Alfalfa Transport from Remote Sites to the Processing Plant (from Volume 1(5.6).

Successful commercial-scale demonstration of renewable biomass power production will stimulate the development and implementation other sustainable energy production systems around the world.

\subsubsection{Employment}

The economics of alfalfa production are calculated to provide equal or higher returns to growers for the production of biomass in the example DFSS rotation when compared to the traditional corn-soybean rotation in the region. Approximately 2000 alfalfa producers will take part in this business to achieve greater economic returns from biomass energy production. These producers (cooperative members) will hire additional labor and spend a portion of their increased returns in the local community.

The processing plant will employ over 50 persons (full time) to produce both electricity and leaf meal products. Over 50 (full time) transportation related jobs and $60-80$ (part time) jobs will be created for storage and handling of the feedstock. Distribution, sales, and marketing of leaf meal products will provide additional economic opportunities.

\subsubsection{New Products}

Alfalfa leaf meal marketing strategies and marketing alliances with other area agricultural cooperatives to evaluate complimentary product sales and marketing opportunities should be investigated. Value-added processing of agricultural commodities can help strengthen declining 
agricultural export markets for raw commodities. Agricultural processing in rural communities creates jobs and new opportunities for young people to remain in rural areas. Shipping raw commodities out of the area, out of the state, and out of the country exports opportunity along with the resource.

\subsection{Environmental Benefits}

\subsubsection{Air}

Biomass energy crops do not contribute net additional carbon dioxide (CO2) to the atmosphere. Fossil fuel combustion releases $\mathrm{CO} 2$ changing the present day balance of gases in the atmosphere and potentially contributing to global climate change (National Biofuels Roundtable report, 1994).

Biomass fuels are generally recognized as clean fuels. Biomass fuels contain very low levels of sulfur and therefore do not contribute significant amounts of sulfur dioxide (SO2, a pollutant that contributes to acid rain) to the atmosphere.

\subsubsection{Water}

Alfalfa fixes its own nitrogen directly from the atmosphere and does not require nitrogen fertilizer. In fact, alfalfa provides fixed nitrogen for following crops in the rotation and has the capacity to remove nitrates from deep soil profiles. Alfalfa production reduces the need for nitrogen fertilizer applications and preferentially removes nitrates from the soil environment reducing the potential for ground and surface water contamination.

Alfalfa provides perennial soil cover essentially eliminating wind and water erosion that contribute to sediment loading of lakes and streams and of non-point source pollution from agricultural lands under alfalfa cover.

The use of pesticides for alfalfa production are minimal and the production of perennial crops in rotation with conventional crops should also reduce pesticide use on crops following alfalfa due to the disruption of pest populations dependant on traditional host crops.

\subsubsection{Soil}

Volume 1 Chapter 10 outlines the potential impacts on the soil and water resources in the proposed biomass shed. An evaluation was made by looking at present land use and soil erosion levels compared with projected soil erosion levels when those same acres are placed in an alfalfabased rotation. The analysis shows that the alfalfa-based rotation would reduce sheet and rill 
water erosion by $60 \%$ and wind erosion by $45 \%$. Targeting fields with high erosion rates as well as on eroding fields with high sediment delivery rates to surface waters for biomass production would maximize environmental benefits.

Alfalfa effects several positive changes in soil properties (Volume 1(10.2)). These influences reduce soil bulk density, increase pore space, and aeration, and provide for better water flow. The absence of tillage during the alfalfa years of the rotation also allows soil structure formation, increased soil organic matter, and enhanced physical and biological soil properties. Most farmers generally recognize improved soil tilth following alfalfa.

The benefits of alfalfa in the rotation are greatest on the fine textured soils. Alfalfa has the greatest impact on improving the internal soil drainage and aeration of these soils, which need tile drainage to effectively grow crops. In wet years enhanced internal drainage on soils previously in alfalfa can positively influence yields about $25 \%$. On average the influence of good internal drainage on yields is about $15 \%$. Alfalfa in a rotation also increases the effectiveness of drainage tile.

\subsubsection{Wildlife}

The Minnesota Department of Natural Resources evaluated the impact of alfalfa biomass energy production on the abundance and diversity of wildlife in the area (Volume 1(10.3)). This report states that the magnitude and direction of impacts depends on the following factors: mowing schedule, availability of overwinter residual cover, cover type replacement, size and shape of fields, distribution of fields, and mowing patterns.

A two-cut biomass energy production harvest schedule with late June and late August mowing dates will have very significant positive impacts on both wildife abundance and diversity. Mowing schedules similar to those used in conventional forage production have significant negative impacts on wildlife.

\subsection{Regional Economic Projections (Costs And Benefits)}

\subsubsection{Social Costs And Benefits}

Alfalfa biomass production will improve the workload schedule for farm operations that add a perennial energy crop to their conventional rotation. Spring and fall field work demands heavy time comittments from most farmers. Perennial crops that are planted once for several years reduce spring planting workload. Reduced harvest frequency for biomass-type alfalfas reduces the total annual labor cost associated with hay production. Reduced cutting schedules using 
currently available alfalfa varieties may also reduce leaf yield per acre resulting in lower returns for alfalfa biomass energy production. Improved biomass-type alfalfa varieties are expected in the very near term (within the next 5 years) and should be available for producers prior to scaleup to full production.

A biomass production and processing cooperative provides a new investment opportunity for producers in the biomass shed. The opportunity to add value to alfalfa is generally recognized as a good opportunity to become more vertically integrated in agricultural markets. Cooperative energy production also reduces production risks and makes other collateral new ventures more achievable as the result of shared investments.

Delivery of the biomass feedstock to the processing plant will result in a 7\% increase-in total additional traffic in the region (Volume 1(5.3)). Although the transportation infrastructure in the region is more than adequate to deal with the increase, the social cost resulting from increased traffic (especially the estimated $37 \%$ increase in heavy commercial traffic anticipated at the plant site) should be carefully considered and properly planned for.

\subsubsection{Environmental Costs And Benefits}

Delaying spring harvest of the alfalfa biomass energy crop until late June has a very positive impact on the nesting success of native bird species and other wildlife. Typical three and four harvest systems have a negative impact on wildlife. Wildlife enhancement incentives may allow early implementation of reduced cutting schedules that would benefit area wildlife and farmers workload situations.

Coal powered electricity production results in a waste by-product, coal ash. Land-filling coal ash has an immediate cost and unknown long-term costs. Biomass ash is potentially a beneficial soil amendment and nutrient source that may contribute to the sustainability of alfalfa production (Volume 1(7.1)).

\subsubsection{Economic Costs And Benefits}

Feedstock production, in state, replaces coal from the western U.S. and contributes to Minnesota's energy self-sufficiency. A $75 \mathrm{MWe}$ coal-fired power plant would consume over $\$ 10$ million dollars of coal annually.

New jobs, new business, new products, and a healthier environment all contribute significant economic benefits to the region. The local perception of economic benefits for the region have 
been very positive (Volume 1(1)). Continued interaction with stakeholders in the region are recommended throughout the development of the proposed energy production system.

Beyond Minnesota, the potential for early implementation of biomass energy production systems across the country and throughout the world rests on our ability to demonstrate these benefits on a commercial scale. Continued cooperation between utilities, agricultural producers, and the public sector will be essential for the successful implementation of sustainable biomass energy production. 



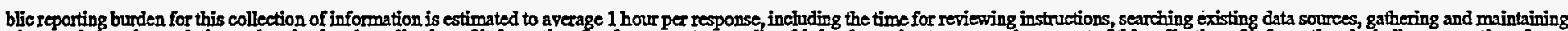

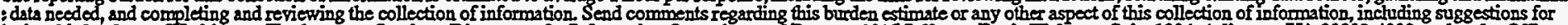

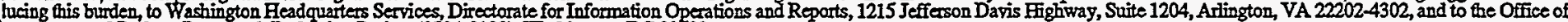
inagement and Budget, Paperwork Reduction Project (07040188), Washington, DC 20503

\begin{tabular}{l|c|c}
\hline $\begin{array}{l}\text { AGENCY USE ONLY (Leave } \\
\text { ank) }\end{array}$ & $\begin{array}{c}\text { 2. REPORT DATE } \\
\text { December 1995 }\end{array}$ & $\begin{array}{c}\text { 3. REPORT TYPE AND DATES COVERED } \\
\text { Final Subcontract Report }\end{array}$ \\
\hline
\end{tabular}

TITLE AND SUBTITLE

Economic Development Through Biomass System Integration: Summary Report

AUTHOR(S)

Max M. DeLong, Ph.D., Principal Investigator
5. FUNDING NUMBERS

(C) AAC- 4-13326-02

(TA) BP51.1010

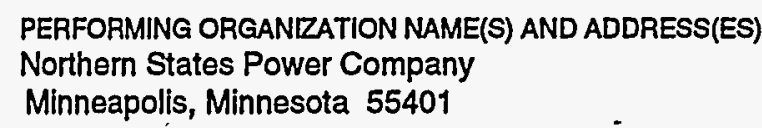
!a. DISTRIBUTIONAVAILABILITY STATEMENT
National Technical Information Service
U.S. Department of Commerce
5285 Port Royal Road
Springfield, VA 22161

\section{ABSTRACT (Maximum 200 words)}

eport documents a feasibility study for an integrated biomass power system, where an energy crop (alfalfa) is the feedstock for a processing ant and a power plant (integrated gasification combined cycle) in a way that benefits the facility owners.
. SUBJECT TERMS
energy conservation, biomass energy production, gasification, biomass power
15. NUMBER OF PAGES 350

8. PERFORMING ORGANIZATION REPORT NUMBER

DE96000496

10. SPONSORINGMONITORING AGENCY REPORT NUMBER

NREL/TP-430-20517

\begin{tabular}{l|l|l}
\hline $\begin{array}{l}\text { SECURITY CLASSIFICATION } \\
\text { OF REPORT }\end{array}$ & $\begin{array}{l}\text { 18. SECURITY CLASSIFICATION } \\
\text { OF THIS PAGE }\end{array}$ & $\begin{array}{l}\text { 19. SECURITY CLASSIFICATION } \\
\text { OF ABSTRACT }\end{array}$
\end{tabular}

16. PRICE CODE

20. LIMITATION OF ABSTRACT 
